\title{
Reimagining Digital Copyright Through the PoWer OF IMITATION: LeSSONS FROM CONFUCIUS AND Plato
}

\author{
Giancarlo Frosio*
}

Forthcoming in 5 Peking University Transnational Law Review (2017) (Draft)

\begin{abstract}
For millennia, Western and Eastern culture shared a common creative paradigm. From Confucian China, across the Hindu Kush with the Indian Mahābhärata, the Bible, the Koran and the Homeric epics, to Platonic mimēsis and Shakespeare's "borrowed feathers," our culture was created under a fully open regime of access to pre-existing expressions and re-use. Creativity used to be propelled by the power of imitation. However, modern policies have largely forgotten the cumulative and collaborative nature of creativity. Actually, the last three decades have witnessed an unprecedented expansion of intellectual property rights in sharp contrast with the open and participatory social norms governing creativity in the networked environment. Against this background, this paper discusses the reaction to traditional copyright policy and the emergence of a social movement re-imagining copyright according to a common tradition focusing on re-use, collaboration, access and cumulative creativity. This reaction builds upon copyright's growing irrelevance in the public mind, especially among younger generations in the digital environment, because of the emergence of new economics of digital content distribution in the Internet. Along the way, the rise of the users, and the demise of traditional gatekeepers, forced a process of reconsideration of copyright's rationale and welfare incentives. Scholarly and market alternatives to traditional copyright have been plenty, attempting to reconcile pre-modern, modern and post-modern creative paradigms. Building upon this body of research, proposals and practice, this Article will finally try to chart a roadmap for reform that reconnects Eastern and Western creative experience in light of a common past, looking for a shared future.
\end{abstract}

\section{INTRODUCTION}

Confucius said: "I transmit rather than create; I believe in and love the ancients."1 Plato-and later Aristotle-made imitation the general principle of art. $^{2}$ Confucius

\footnotetext{
* Senior Lecturer and Researcher, Centre for International Intellectual Property Studies (CEIPI), University of Strasbourg; Non-Resident Fellow, Stanford Law School, Center for Internet and Society. The author can be reached at gcfrosio@ ceipi.edu. Please note that most materials cited in this paper include an embedded link. Please also note that portions of this essay have already been published in Giancarlo F. Frosio, Resisting the Resistance: Resisting Copyright and Promoting Alternatives, 23 RiCH. J. L. TECH. 4 (2017).
} 
ideas of creativity resemble closely that of Plato and pre-modern Western tradition. Art was mimēsis of reality, Plato said. In Plato's view, poetry, music, dance-and art generally-imitated reality. In his Poetics, Aristotle added that imitation is the distinctive character of humanity: "indeed we differ from other animals in being most given to mimēsis and in making our first steps in learning through it - and pleasure in instances of mimēsis is equally general."3 Li Mengyan, late Ming scholar, followed in Confucius' footsteps and somehow echoed Aristotle's arguments on the natural origins of imitation. In praising imitation and explaining the need to address the past, Mengyan contended that "the rules used by the ancients were not invented by them but really created by Nature ... . [so that] when we imitate the ancients, we are not imitating them but really imitating the natural law of things." 4 The focus on transmission, tradition and past has been a companion to Eastern and Western literature equally for a very long time. In $\mathrm{Wu}$ Li's opinion, "to paint without taking the Sung and Yuan masters as one's basis is like playing chess on an empty chessboard, without pieces." 5 Nullumst iam dictum quod non sit dictum prius, Terence first noted. ${ }^{6}$ In the Prologue to The Canterbury Tales and other passages, Chaucer presents himself as a mere compiler or translator. ${ }^{7}$ To Chaucer, the act of writing was gleaning the harvest of poetry reaped by others:

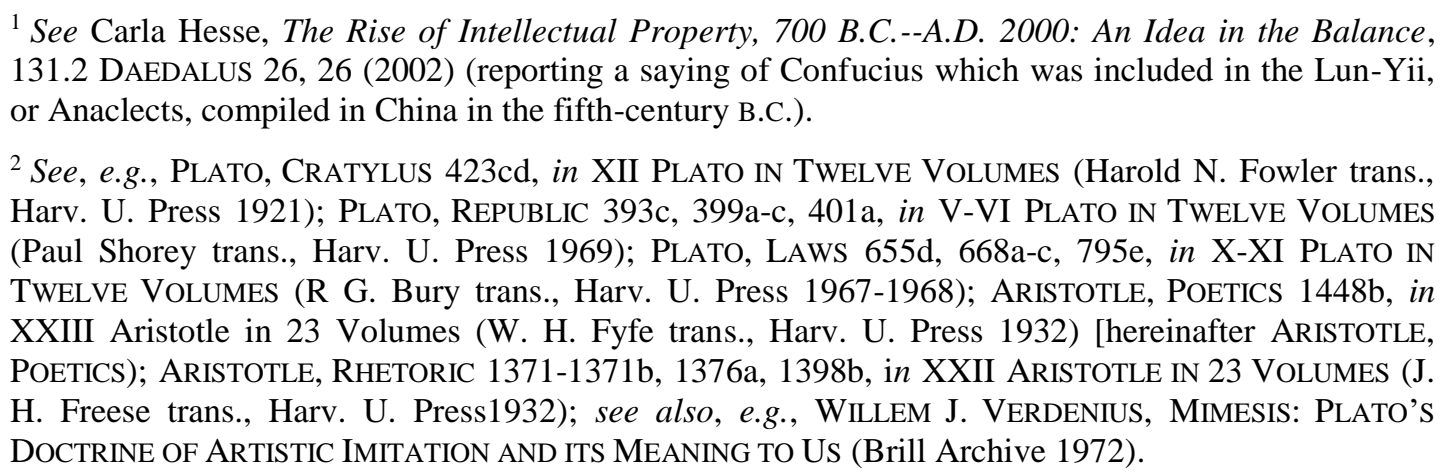

${ }^{3}$ See ARISTOTLE, PoEtics, supra note 2, at 1448b.

${ }^{4}$ See William P. Alford, To Steal a Book Is an Elegant OfFense: Intellectual Property LAW IN Chinese Civilization 27 (Stanford U. Press 1995).

${ }^{5}$ See ALFORD, supra note 4, at 28.

${ }^{6}$ Publius Terentius Afer, Eunuchus ln. 41 (161 B.C. circa), in I Terence: The LAdy OF ANDros, The SElF-Tormentor, THE EunuCH 238 (John Sargeaunt trans., W. Heinemann 1918) ("In fact nothing is said that has not been said before").

7 See Andrew Bennett, The Author 42 (Routledge 2005); see also Sebastian Coxon, The PRESENTATION OF AUthorship IN MEdiEVAL GERMAN NARRATIVE LiteratURE 1220-1290 7 (Clarendon Press 2001) (mentioning that many well-known German authors of the mid-twelfth and thirteenth century often professed their works to be translations of French and Latin source texts). 
For wel I wot that folk han here-beforn / Of Makyng ropen [reaped the harvest of poetry], and lad away the corn; / and I come after, glenynge here and there / And am ful glad if I may fynde an ere / Of any goodly word that they han left. ${ }^{8}$

At the time of the Renaissance workshop, Duke Cosimo De' Medici is reported to have said that in case of copies that deceive against the original "the copy should be preferred to the original because it contained both skills, that of the originator and that of the copier." Shen Zhou reacted to those asking to put a stop to the forging of its work by saying: "if my poems and paintings, which are only small efforts to me, should prove to be of some aid to the forgers, what is there for me to grudge about?"10 From Lucian to Confucius, later Chaucer and many others, there was a well-marked perception that creativity was forged by deep cumulative mechanics and imitation was its ally, rather than its enemy.

For millennia, Western and Eastern culture shared a common creative paradigm. From Confucian China, across the Hindu Kush with the Indian Mahābhārata, the Bible, the Koran and the Homeric epics, to African xhosa imbongi and European troubadours, our culture was created under a fully open regime of access to preexisting expressions and re-use. From Platonic mimēsis to Shakespeare's "borrowed feathers," culture was produced under a paradigm in which imitation-even plagiarism-and social authorship formed constitutive elements of the creative moment. ${ }^{11}$ Before Romanticism ignited a process of complete commodification of creative artifacts in Western society, market exchange models ran parallel to gift exchange. Indeed, for many centuries, creativity has been repeatedly construed as a gift according to the belief in scientia donum dei est, unde vendi non potest. ${ }^{12}$ Confucian ideals endorsed a matching vision as proved by the Chinese aphorism "genuine scholars let the later world discover their work rather than promulgate and profit from it themselves." ${ }^{\prime 3}$ Confucianism finds here an easy parallel with Platonism and its disrespect for Sophists, taking fees for their teachings.

Yet somehow the cumulative, freewheeling nature of creativity seems to find little recognition in modern copyright policies, which build upon a post-Romantic individualistic view emphasizing absolute originality rather than imitation. As

\footnotetext{
${ }^{8}$ See Geoffrey Chaucer, The Legend of Good Women, Prologue, G version 61-5, as cited in JOHN A. Burrow, MEdieval Writers AND Their Works: Middle English Literature AND ITS BACKGROUND, 1100-1500 34 (Oxford U. Press 1982).

${ }^{9}$ GiUlio Mancini, Considerazioni sulla PitTURA 135 (Accademia Nazionale dei Lincei 1956) (1619).

${ }^{10}$ Wen Fong, Problem of Forgeries in Chinese Paintings, 25(2-3) Artibus Asiae 95, 100 (1962).

${ }^{11}$ See Giancarlo F. Frosio, Rediscovering Cumulative Creativity from the Oral-Formulaic Tradition to Digital Remix: Can I Get a Witness? 13(2) J. MARShall ReV. InTELl. Prop. L. 341, 376-390 (2014).

12 See Giancarlo F. Frosio, User Patronage: The Return of the Gift in the "Crowd Society”, 2015(5) MicH. ST. L. REV. 1983, 2036-2039 (2015).

${ }^{13}$ ALFORD, supra note 4, at 28.
} 
Willian Alford explained in To Steal a Book is an Elegant Offence: Intellectual Property Law in Chinese Civilization, the same cultural transformation brought about by the Enlightenment and Romantic individualistic experience has not occurred in China nor anywhere else in the non-Western world. ${ }^{14}$ However, as too often forgotten, North, South, East, and West have long shared a cumulative, collaborative, communitarian and open-access creative model. For the majority of human cultural history, economic incentive occupied a secondary role in motivating authors to create. Creativity was mainly a matter of participation. Nonetheless, under a regime of limited economic incentive for creation and confined commodification of information, humanity produced the greatest portion of its culture and knowledge.

The tensions that have historically characterized the nature and the economics of creativity present a cyclical recurrence that obtains even in the digital domain. After being sidelined in the post-Romantic cultural paradigm, cumulative creativity and gift economy are enjoying increasing emphasis in the networked society. Such a long historical view recontextualizes today's digital creativity, user-generated content, and remix culture within a framework of tensions between communal and individual creative expression. The intensifying conflict between market economies and gift economies calls into question not only the institution of copyright law but the wider economic structure it subserves.

Today, in an era of networked mass collaboration, ubiquitous online fan communities, user-based creativity, and digital memes, the enclosure of knowledge brought about by an ever-expanding copyright paradigm seems anachronistic, and a deliberate defiance of inevitable cultural evolution. Aptly, Madhavi Sunder has noted that

from MGM v. Grokster, to new licenses from the Creative Commons for developing nations, to the rise of Internet auteurs of fan fiction, mash-ups, and machinima, to efforts to deliver medicines to the world's poor, to demands for "Geographical Indications" for sarees and other crafts of the developing world, and to the nascent global movement for "Access to Knowledge," traditional economic analysis fails to

\footnotetext{
${ }^{14}$ Id. (examining the law of intellectual property in China from imperial times to the present and locating in the absence of the Enlightenment and Romantic individualistic experience the reason why such protection for scientific and artistic creations is more rhetoric than reality on the Chinese mainland). Please consider, however, that some Chinese scholars, like Chengsi Zheng and Sanquiang Qu noted in response to Alfred that Chinese copyright protection can be traced back to the Song Dynasty. See 郑成思，再论中国古代的版权保护，载中国专利与商标，1996 年第 4 期 [Chengsi Zheng, Re-discussion on Copyright Protection in Ancient China, 4 CHINESE PATENTS AND TradeMARKS (1996)]; see also WenWEi GuAN, INTEllectual Property THEORY AND PRACTICE: A CRITICAL EXAMINATION OF CHINA's TRIPS COMPLIANCE AND BEYOND 46-47 (Springer 2014) (noting that some of protection of publishers' rights against unauthorized reproduction were enacted during the Song Dynasty starting form 1068 AD).
} 
capture fully the struggles at the heart of local and global intellectual property law conflicts. ${ }^{15}$

Strong copyright protection-spearheaded by copyright's principle of exclusivity and strict control over derivative reuses-has turned creativity into an exclusive rather than inclusive process, as it was traditionally for most of our cultural history. In contrast, inclusivity has become the norm of the participative process that seems to characterise creativity in the networked environment. Overbroad copyright protection-insofar as it promotes enclosure, commodification and fragmentation of knowledge-runs counter to newly emphasised interest in the free flow of information and production of knowledge in the digital domain. In this respect, opportunities that digitisation and Internet distribution offer to our society make enclosure and commodification of our information environment even more troublesome.

Today, the greater capacity for the dissemination of knowledge, for cultural creativity and for scientific research carried out by means of the enhanced facilities of computermediated telecommunication networks, has greatly raised the marginal social losses that are attributable to the restrictions that those adjustments in the copyright law have placed upon the domain of information search and exploitation. ${ }^{16}$

Today, we are in the midst of a war over the future of our cultural and information policies. The preamble of the Washington Declaration on Intellectual Property and the Public Interest explains the terms of this struggle:

[t]he last 25 years have seen an unprecedented expansion of the concentrated legal authority exercised by intellectual property rights holders. This expansion has been driven by governments in the developed world and by international organizations that have adopted the maximization of intellectual property control as a fundamental policy tenet. Increasingly, this vision has been exported to the rest of the world. Over the same period, broad coalitions of civil society groups and developing country governments have emerged to promote more balanced approaches to intellectual property protection. These coalitions have supported new initiatives to promote innovation and creativity, taking advantage of the opportunities offered by new technologies. So far, however, neither the substantial risks of intellectual property maximalism, nor the benefits of more open approaches, are adequately understood by most policy makers or citizens. This must change if the notion of a public interest distinct from the dominant private interest is to be maintained. ${ }^{17}$

\footnotetext{
${ }^{15}$ Madhavi Sunder, IP3, 59 STAN. L. REV. 257, 258 (2006); see also Olufunmilayo B. Arewa, Culture as Property: Intellectual Property, Local Norms and Global Rights (2007).

${ }^{16}$ Paul A. David and Jared Rubin, Restricting Access to Books on the Internet: Some Unanticipated Effects of U.S. Copyright Legislation, 5 REV. ECON. RES. COPYRIGHT IsSUES 23, 50 (2008).

17 The Washington Declaration on Intellectual Property and the Public Interest (August 25.27, 2011), Preamble, http://infojustice.org/washington-declaration-html. See also Sebastian Haunss, The Politicisation of Intellectual Property: IP Conflicts and Social Change, 3 WIPO J. 129 (2011).
} 
In the past few years, a global movement grew under the understanding that focusing our attention on the propulsive value of cumulative reuses is pivotal to any discourse about challenges ahead for knowledge governance and principles that should drive our policies for creativity. This movement resisted copyright overexpansion, "resisted the resistance" to the Digital Revolution, ${ }^{18}$ while re-imagining copyright, seeking access to knowledge and promoting the public domain. It lies at the crossroad between academic investigation, civic involvement, and political activity. The Pirate Party may serve as an extreme expression of the sentiment of distaste or disrespect for copyright. In the aftermath of the legal battles targeting $p 2 p$ platforms, the Pirate Party emerged in Sweden to contest elections on the basis of the abolition or radical reform of intellectual property-copyright, in particular. ${ }^{19}$ Meanwhile, Creative Commons, the Free Software Foundation and the Open Source movement, ${ }^{20}$ propelled the diffusion of viable market alternatives to traditional copyright management. The "power of open," as Catherine Casserly and Joi Ito have termed Creative Commons, has spread fast with more than four hundred million CClicensed works available on the Internet. ${ }^{21}$ Again, mostly driven by scholarly efforts, an Access to Knowledge (A2K) Movement, an Open Access Publishing Movement, a Public Domain Project and Cultural Environmentalism sought to re-define the hierarchy of priorities embedded in the traditional politics of intellectual property. Meanwhile, several proposals have been trying to re-imagine copyright norms to adapt them to digitization and digital creativity.

\footnotetext{
${ }^{18}$ See Eben Moglen, Professor, Free and Open Software: Paradigm for a New Intellectual Commons, speech given at the Law of the Commons Conference at Seattle University (March 13, 2009), transcript available at http://en.wikisource.org/wiki/Free and_Open_Software:_Paradigm for_a_New_Intellectual_Commons (crafting this notion of "resisting the resistance").
}

${ }^{19}$ See, See Piratpartiet, International, The Pirate Party, http://www.piratpartiet.se/international/english (proclaiming that "[t]he monopoly for the copyright holder to exploit an aesthetic work commercially should be limited to five years after publication. A five years copyright term for commercial use is more than enough. Non-commercial use should be free from day one"); CHRISTIAN ENGSTRÖM AND Rick Falkvinge, The CASE FOR COPYRIGHT REForm (The Swedish Pirate Party \& Greens/EFA EP 2012), available at http://www.copyrightreform.eu; see also Miaoran Li, The Pirate Party And The Pirate Bay: How The Pirate Bay Influences Sweden And International Copyright Relations, 21 PACE InT'L L. ReV. 281 (2009); Jonas Anderson, For the Good of the Net: The Pirate Bay as a Strategic Sovereign, 10 Culture Machine 64 (2009); Neri LuCA, LA Baia deI PiRAti: Assalto AL COPYRIGHT (Cooper Editore 2009).

${ }^{20}$ See, e.g., Moglen Eben, Freeing the Mind: Free Software and the Death of Proprietary Culture, June 29, 2003; Moglen Eben, Anarchism Triumphant: Free Software and the Death of Copyright, June 28, 1999, available at http://emoglen.law.columbia.edu.

${ }^{21}$ See Catherine Casserly and Joi Ito, The Power of Open (Creative Commons 2011), http://thepowerofopen.org; see also Niva Elkin-Koren, Exploring Creative Commons: A Skeptical View of a Worthy Pursuit, in THE Future OF THE PUBlic DOMAIN: IDENTIFYING THE COMMONS IN INFORMATION LAW 325-345 (Lucie Guibault and P. Bernt Hugenholtz eds., Kluwer Law International 2006). 


\section{REIMAGINING COPYRIGHT: NOTIONS AND ECONOMICS}

Copyright law has fallen into a profound crisis of legitimacy. Both users and creators have largely withdrawn any support for copyright. ${ }^{22}$ Especially with new generations, ${ }^{23}$ copyright tends to become irrelevant in the public mind, ${ }^{24}$ if not altogether opposed. David Lange noted that the over-expansion of copyright entitlements lies at the backbone of their withering public acceptance:

Raymond Nimmer has said that copyright cannot survive unless it is accorded widespread acquiescence by the citizenry. I think his insight is acutely perceptive and absolutely correct, for a reason that I also understand him to endorse: Never before has copyright so directly confronted individuals in their private lives. Copyright is omnipresent. But what has to be understood as well is that copyright is also correspondingly over-extended. ${ }^{25}$

The Australian Government Productivity Commission builds upon this point, highlighting its practical implications. In the Commission's view, the "copy(not)right" model does fail its goals for a number of critical reasons:

Australia's copyright arrangements are weighed too heavily in favour of copyright owners, to the detriment of the long-term interests of both consumers and intermediate users. Unlike other IP rights, copyright makes no attempt to target those works where 'free riding' by users would undermine the incentives to create. Instead, copyright is overly broad; provides the same levels of protection to commercial and noncommercial works; and protects works with very low levels of creative input, works

22 See, e.g., JessicA Silbey, The EurekA Myth: CREATORS, InNOVATORS, AND Everyday INTELLECTUAL PROPERTY (Stanford University Press 2015) (finding, after collecting interview-based empirical data, that suggesting that creators - and even businesses - need intellectual property and exclusivity overstates, if not misstates, the facts and explaining how this misunderstanding about creativity sustains a flawed copyright system); Jessica Litman, Real Copyright Reform, 96 IowA L. REV. 1, 3-5, 31-32 (2010) (noting that "the deterioration in public support for copyright is the gravest of the dangers facing the copyright law in a digital era [ . . ] [c]opyright stakeholders have let copyright law's legitimacy crumble"'); JOHN TEHRANIAN, INFRINGEMENT NATION: COPYRIGHT 2.0 AND YOU xvi-xxi (Oxford University Press 2011); Copyright and Wrong: Why the Rules on Copyright need to Return to Their Roots, THE ECONOMIST, April 8, 2010, available at http://www.economist.com/displayStory.cfm?story $\mathrm{id}=15868004$ (arguing that copyright should return to its roots, because as it is now it may cause more harm than good

23 See Future of the Internet, Pew Research Center's Internet \& American Life Project, http://pewinternet. org/topics/Future-of-the-Internet.aspx; EUROPEAN OBSERVATORY ON INFRINGEMENTS OF INTELLECTUAL PROPERTY RIGHTS, THE EUROPEAN CITIZENS AND INTELLECTUAL PROPERTY: PERCEPTION, AWARENESS AND BEHAVIOUR 11-14, 54-59 (2013) (noting that the copyright systems suffers from a lack of legitimacy in the eyes of young generations).

${ }^{24}$ See Brett Lunceford and Shane Lunceford, The Irrelevance of Copyright in The Public Mind, 7 Nw. J. TECH. \& INTELL. PROP. 33 (2008).

${ }^{25}$ David Lange, Reimagining the Public Domain, 66 LAW \& CONTEMP. PROBS. 475, 471 (2003). 
that are no longer being supplied to the market, and works where ownership can no longer be identified. ${ }^{26}$

Technology — and the cultural change it brought about — played a significant role in lowering copyright's acceptance. In a message delivered to the G20 leaders, Dimity Medvedev pointed out that " $[\mathrm{t}]$ he old principles of intellectual property protection established in a completely different technological context do not work any longer in an emerging environment, and, therefore, new conceptual arrangements are required for international regulation of intellectual activities on the Internet." ${ }^{27}$ Francis Gurry noted that

[d]igital technology and the Internet [. . .] have given a technological advantage to one side of the [copyright] balance, the side of free availability, the consumer [. . .] History shows that it is an impossible task to reverse technological advantage and the change that it produces. Rather than resist it, we need to accept the inevitability of technological change and to seek an intelligent engagement with it. There is, in any case, no other choice - either the copyright system adapts to the natural advantage that has evolved or it will perish. ${ }^{28}$

Digitization led to challenge the obsolescence of the traditional copyright monopoly, seeking reform. In 1994, John Perry Barlow radically concluded that: "in the absence of the old containers, almost everything we think we know about intellectual property is wrong". ${ }^{29}$ Nicholas Negroponte reinforced Barlow's point by stating that "copyright law is totally out of date [ . . ] it is a Gutenberg artifact [ ... ] since it is a reactive process, it will have to break down completely before it is corrected." "Recently, the Hargreaves report observed that archaic copyright laws might be "obstructing innovation and economic growth." ${ }^{31}$ Many highlighted the necessity of re-shaping present copyright ${ }^{32}$ or abolishing it altogether. ${ }^{33}$ In particular,

26 Australian Productivity COMmission, Intellectual Property Arrangements, Draft REPORT 16 (Canberra, 2016), https://assets.documentcloud.org/documents/2819862/IntellectualProperty-Draft.pdf.

27 Dmitry Medvedev's message to the G20 leaders, President of Russia (November 3, 2011), http://eng.krem lin.ru/news/3018.

${ }^{28}$ Francis Gurry, The Future of Copyright, speech delivered at the Blue Sky Conference: Future Directions in Copyright Law, Queensland University of Technology, Brisbane, Australia (February 25, 2011), available at http://www.wipo.int/about-wipo/en/dgo/speeches/dg blueskyconf_11.html.

${ }^{29}$ John Perry Barlow, Selling Wine Without Bottles: The Economy of Mind on the Global Net, WIRED 2.03 (1994).

${ }^{30}$ Nicholas Negroponte, Being Digital 58 (Alfred A. Knopf 1995).

31 See IAn Hargreaves, Digital OpPortunity. A ReView of Intellectual Property AND GROWTH 5 (May 2011).

32 See, e.g., in addition to many other authors already cited, Pamela Samuelson, The Copyright Principles Project: Directions for Reform, 25 BERKELEY TECH. L. J. 1175 (2010); WILLIAM PATRY, How to FIX COPYRIGHT (Oxford U. Press 2012); Guy Pessach, Reciprocal Share-Alike Exemptions In Copyright Law, 30 CARDOZO L. REV. 1245 (2008); Jessica Litman, Sharing and Stealing, 27 
a growing copyright "abolitionism" emerged online in response to a tendency to criminalise the younger generation and new models of online digital creativity, such as mash-up, fanfiction, or machinimia. The Committee on Intellectual Property Rights and the Emerging Information Infrastructure considered that the notion of copying might not be an appropriate mechanism for achieving the goals of copyright in the digital age. Among the reasons of the inadequacy of the notion, the Committee highlights that "in the digital world copying is such an essential action, so bound up with the way computers work, that control of copying provides, in the view of some, unexpectedly broad powers, considerably beyond those intended by the copyright law." ${ }^{34}$ As sharing becomes a basic form of human interaction to an emerging digital culture, Lessig has called for an overhaul of the copyright system, which will "never work on the internet" and "[i]t'll either cause people to stop creating or it'll cause a revolution." 35

Ubiquitous technology, cost minimization, and User-Generated Content UGC radically affected the traditional market failure that copyright is supposed to cure, both at the creation and distribution levels. The Internet instituted new economics of

Hastings Comm. \& EnT. L. J. 1 (Fall 2004); Mark Lemley and Anthony Reese, Reducing Digital Copyright Infringement Without Restricting Innovation, 56 STAN. L. REV. 1345 (May 2004); Landes William M. \& Richard A. Posner, Indefinitely Renewable Copyright, 70 U. CHI. L. REV. 471 (2003).

${ }^{33}$ Legal scholars have long recognized that copyright and patent are not the only options. See, e.g., Michele Boldrin AND DAVID K. Levine, AgAinst Intellectual Monopoly (Cambridge University Press 2008) (disputing the utility of intellectual property altogether); Stephen Breyer, The Uneasy Case for Copyright: A Study of Copyright in Books, Photocopies, and Computer Programs, 84 HARV. L. REV. 281, 282 (1970) (concluding "[i]t would be possible, for instance, to do without copyright, relying upon authors, publishers, and buyers to work out arrangements among themselves that would provide books' creators with enough money to produce them."); Jon M. Garon, Normative Copyright: A Conceptual Framework for Copyright Philosophy and Ethics, 88 CORNELL L. REV. 1278, 1283 (2003) (noting "[u]nless there is a valid conceptual basis for copyright laws, there can be no fundamental immorality in refusing to be bound by them . . ..”); JOOST SMIERS AND MARIEKE VAN SCHIJNDEL, IMAGINE THERE IS NO COPYRIGHT AND NO CULTURAL CONGLOMERATES TOO (Institute of Network Culture 2009); Joost Smiers and Marieke Van Schijndel, Imagining a World Without Copyright: the Market and Temporary Protection, a Better Alternative for Artists and Public Domain, in COPYRIGHT AND OTHER FAIRY TALES: HANS CHRISTIAN ANDERSEN AND THE COMMODIFICATION OF CREATIVITy 129 (Helle Porsdam ed., Edward Elgar Publishing Ltd. 2006). For an historical and empirical argument against copyright, see Frank Thadeusz, No Copyright Law: The Real Reason for Germany's Industrial Expansion?, SPIEGEL ONLINE, August 18, 2010, http://www.spiegel.de/international/ zeitgeist/0,1518,710976,00.html.

34 National Research BoARd, The Digital Dilemma: Intellectual Property IN The INFORMATION AGE 140 (National Academy Press, 2000).

35 See Larry Lessig, speech at the WIPO Global Meeting on Emerging Copyright Licensing Modalities - Facilitating Access to Culture in the Digital Age, Geneva, Switzerland (November 4, 2010), available at http://www.freedomtodiffer.com/freedom to_differ/2010/11/larry-lessig-calls-forwipo-to-lead-radical-overhaul-of-copyright-law.html. 
distribution for digital content. ${ }^{36}$ Distribution and reproduction marginal costs being close to zero potentially eliminates - or at least strongly reduces - the need for thirdparty investment. In The Creative Destruction of Copyrights, Raymond $\mathrm{Ku}$ applies the metaphor of Schumpeter's wind of creative destruction to the digital revolution and wonders whether a copyright monopoly at close to zero marginal cost is still a sustainable option. ${ }^{37} \mathrm{Ku}$ concludes that-absent the need for encouraging content distribution - the artificial scarcity created by copyright cannot find social reasons for existence. In any event - from a less radical perspective-if technological innovation led to a substantial reduction in production, reproduction and distribution costs of cultural artifacts, a case could be made at least against the steady copyright monopoly's expansion that have been occurring for the past few decades.

In addition, minimization of reproduction and distribution costs affected traditional welfare analysis regarding creative incentive. Reductions in the production and distribution costs of original expressive works encourages nonprofessional authors to create. ${ }^{38}$ Therefore, the number of authors for whom the lucre of copyright proves a necessary stimulus should drop. Additionally, low marginal costs empower few authors to reach a broader audience. If decentralized and unprofessional authors increasingly satisfy the market demand-because nonmonetary incentives stimulate creation - a copyright monopoly will eventually prove superfluous, at least for these works. the burdens of a copyright monopoly will exceed its benefits, at least for works created by decentralized and non-professional authors.

\section{REIMAGINING USERS}

Quite provocatively, Lindberg and Patterson argued that the true nature of copyright law is to be a users' right. ${ }^{39}$ However, as Julie Cohen noted, "[c]opyright doctrine [. . .] is characterized by the absence of the user [. . .] the resulting imbalance-empty space where one cornerstone of a well-balanced copyright edifice

\footnotetext{
${ }^{36}$ See Sacha Wunsch-Vincent, The Economics of Copyright and the Internet: Moving to an Empirical Assessment Relevant in the Digital Age (World Intell. Prop. Org., Economic Research Working Paper No. 9, 2013) at 2 .

${ }^{37}$ See Raymond S. R. Ku, The Creative Destruction of Copyrights: Napster and the New Economics of Digital Technology, 69 u. Chi. L. Rev. 263, 300-305 (2002); Ku, Raymond S. R., Consumers and Creative Destruction: Fair Use Beyond Market Failure, 18 BERKELEY TECH. L. J. 539 (2003); see also Paul Ganley, The Internet, Creativity and Copyright Incentives, 10 J. INTELL. ProP. RTS. 188 (2005); John F. Duffy, The Marginal Cost Controversy in Intellectual Property, 71 U. CHI. L. REV. 37 (2004).

${ }^{38}$ See Tom W. Bell, The Specter of Copyism v. Blockheaded Authors: How User-Generated Content Affects Copyright Policy, 10 VAND. J. ENT. \& TECH. L. 841, 851-855 (2008).

39 See Ray L. Patterson And Stanley W. Lindberg, The NAture of Copyright: A LAW OF USERS’ RIGHTS (University of Georgia Press 1991).
} 
should be - makes for bad theory, bad policy, and bad law." 40 In particular, the marginalization of the user has reverberated on the role of the user in the legislative process. The public has always had very limited access to the bargaining table when copyright policies had to be enacted. This is due to the dominant mechanics of lobbying that largely excluded the users from any decision on the future of creativity management. ${ }^{41}$ In accordance with Mançur Olson classical work, copyright policy is driven by a small group of concentrated players to the detriment of the more dispersed interest of smaller players and the public at large. ${ }^{42}$ The consequence of users' marginality reflects on democratization. Boyle made this point straightforward by noting:

[i]n both environmental protection and intellectual property, the very structure of the decision making process tends to produce a socially undesirable outcome. Decisions in a democracy are made badly when they are primarily made by and for the benefit of a few stakeholders, be they landowners or content providers. It is a matter of rudimentary political science analysis or public choice theory to say that democracy fails when the gains of a particular action can be captured by a relatively small and well-identified group while the losses - even if larger in the aggregate-are low-level effects spread over a larger, more inchoate group. This effect is only intensified when the transaction costs of identifying and resisting the change are high. ${ }^{43}$

As a related problem, often the copyright legislative process has appeared to be biased by a large amount of lack of transparency and due process. The AntiCounterfeiting Trade Agreement (ACTA) was a good example of secrecy in the process of enacting copyright and intellectual property laws. ${ }^{44}$ ACTA was a secret treaty-negotiated away from the UN, behind closed doors - that could impinge heavily on citizens' freedoms and privileged uses. Nevertheless, users were completely excluded from the bargaining table, while information on the negotiations and relevant provisions included in the agreement have been for long time scarce and contradictory.

\footnotetext{
${ }^{40}$ Julie Cohen, The Place of the User in Copyright Law, 74 FordHAM L. REv. 347, 347-348 (2005).

${ }^{41}$ For an account of copyright industry political influence in the U.S. and worldwide, see JESSICA LitMan, Digital Copyright 22-69, 122-150 (Prometheus Books 2001); see also Neil Netanel, Why Has Copyright Expanded: Analysis and Critique, in 6 NEW DiRECTIONS IN COPYRIGHT LAW 3-11 (Fiona Macmillan ed., Edward Elgar Publishing 2007); JAMES BoYle, The Public Domain: ENCLOSING THE COMMONS OF THE MIND 50-51 (Yale University Press 2009).

${ }^{42}$ See Mançur Olson, The Logic of Collective Action: Public Goods and the Theory of GROUPS (Harvard U. Press 1971) (1965).

${ }^{43}$ Boyle, supra note 144, at 110.

${ }^{44}$ See Luc Pierre Devigne, Pedro Velasco-Martins and Alexandra Iliopoulou, Where Is ACTA Taking US? Policies and Politics, in COPYRIGHT ENFORCEMENT AND THE INTERNET 39-40 (Irini A. Stamatoudi ed., Wolters Kluwer 2010).
} 
Further, commentators argued that copyright law is too obscure and complex for the users. ${ }^{45}$ Copyright law is drafted for the market players, not for users. Let's take as an example Article 6(4) of the Information Society Directive. Lucie Guibault describes it as "extremely complex, vague and prone to interpretation." 46 It is illustrative to observe that the provision refers to actions to be taken to ensure that users may benefit form exceptions and limitations with respect to works protected by technological protection measures. Often, the obscurity of copyright law causes a high level of uncertainty among users regarding what they can or cannot do with creative content. Fair uses become "feared uses," when complexity of copyright provisions discourage users from enforcing privileged or fair uses. Meanwhile, copyright morphs from a defensive legal tool into an offensive tool to promote market dominance. Increasing users' involvement in the creative process exacerbates this imbalance. The Internet 2.0 and user-generated platforms have made everybody a potential author as well as a potential infringer. Therefore, heavily technical legislation is increasingly enforced against users.

Lobbying from cultural conglomerates played a key role in amplifying the process of copyright expansion beyond strict public interest. Public domain's enclosure has resulted from the asymmetric distribution of power in IP politics and the difficulty of representing public interest due to an unbalanced legislative process. So far, copyright matters have been considered entertainment industry sector specific issues. The absence of the users reflected into a pro-distributors copyright system, featuring an overbroad expansion of private property rights and corresponding restriction of public prerogatives.

Today, however, the community is reclaiming - and regaining-its role in the discourse about creativity. Users drove Internet change. They brought about a bottom-up revolution that challenged traditional social and market mechanics based on an opposite top-down paradigm. Mass culture and networked collaboration emphasize the centrality of the user in post-modern creativity. Then, the digital environment saw the emerge-or re-emergence-of a concept of authorship mingling users and authors together. Therefore, as copyright moves into the digital age, the absence of the user has begun to matter profoundly and "a theory of authors" rights must be informed by a theory of user as well." 47

\footnotetext{
45 See Litman, supra note 22, at 3-5, 33-34 (2010) (calling for a radical simplification of copyright law "unless our goal is to make it impossible for creators, distributors, and readers to navigate the copyright system without representation").

${ }^{46}$ Lucie Guibault, Evaluating Directive 2001/29/EC in the light of the Digital Public Domain, paper presented at the 1st COMMUNIA Conference (July 1, 2008), at 10; see also LUCIE GUIBAULT ET AL., STUdy ON THE IMPLEMENTATION AND EFFECT IN MEMBER STATES' LAWS OF DiRECTIVE 2001/29/EC ON THE HARMONISATION OF CERTAIN ASPECTS OF COPYRIGHT AND RELATED RIGHTS IN THE INFORMATION SOCIETY 105 (report prepared for the European Commission, ETD/2005/IM/D1/91, February 2007).

${ }^{47}$ Cohen, supra note 40 , at 348.
} 
First, a politics of users - and inclusive - rights should be primarily based on cleansing the legislative process from the dominance of the market. ${ }^{48}$ This might be achieved by seeking transparency through an evidence-based approach in policy making. In this regard, a welfare cost-benefit analysis could become a prerequisite for enacting new legislation. In particular, legislators should base decisions only on independent empirical evidence showing whether the creative market as a wholerather than niches and lobbying groups-might justify policy reforms or new enforcement strategies. ${ }^{49}$ Even if sellers' revenues decreased what should matter for policy purposes, should only be the surplus consumers derive - in particular whether policy strategies encourage or not creative output. Actually, this policy approach would endorse constitutional prescriptions in the United States and dominant welfare theory principles in Europe and elsewhere. Obviously, if strictly applied, this approach might lead to substantially different policy strategies than the current. ${ }^{50}$ Also, users' representation should be enhanced in the policy making process. Options are plenty and easy to enforce. For example, the creation of advisory bodies, such as the German KulturRat, ${ }^{51}$ might strengthen users' representation. Again, a public interest or public domain supervisor-whose mandatory opinion would be requested to formulate and enact knowledge based policies - might act as a guardian of users' fundamental rights. ${ }^{52}$

Second, this theory should help reconciling a paradigm of exclusive rights to one of inclusive rights, policing creativity from a communitarian rather than an individualistic perspective. The regained emphasis on the community in digital creativity bridges the gap between the first and the second paradigm into the third

${ }^{48}$ Indeed, this is a structural problem extending beyond creativity related policy. See LAWRENCE LESSIG, REPUBLIC LOST: How MONEY CORRUPTS CONGRESS - AND A PlAN TO STOP IT (Twelve 2011) (discussing imbalances caused by lobbying in the Congress as a natural development of having spearheaded a movement for the protection of digital user rights against copyright over-expansion because the primary problem with modern intellectual property policies is the invisibility of the users and the marginalization of public interest within the legislative process).

${ }^{49}$ See The Copyright Evidence Wiki: Empirical Evidence for Copyright Policy (Theo Koutmeridis, Kris Erickson, K., Martin Kretschmer (eds.), CREATe Centre: University of Glasgow, 2015), www.CopyrightEvidence.org (accessed December 15, 2016) (trying to establish a body of evidence that allows better decision making in the contested copyright policy field); see also Raymond Shih Ray Ku, Jiayang Sun, Yiying Fan, Does Copyright Law Promote Creativity - An Empirical Analysis of Copyright's Bounty, 62 VAND. L. REV. 1667 (2009) (noting that there's no consistent relationship between copyright protection and output).

${ }^{50}$ Joel Waldfogel, Bye, Bye, Miss American Pie: The Supply of New Recorded Music since Napster, (NBER Working Paper Series No. 16882, March 2011), at 24 (noting that it is "clear that creative output in recorded music is as high, or higher, than it was prior to Napster").

${ }^{51}$ See http://www.kulturrat.de

52 See Alexander Peukert, A European Public Domain Supervisor, 42 InT'L REV. InTEL. Prop. COMP. L. 125 (2011). 
that elevates users' rights as the Grundnorm of creativity policies, ${ }^{53}$ rather than the exception. Policy makers should be prepared to ask whether the user "would be better served by a system that limits the rights of copyright owners more narrowly in the first instance." 54 A few policy options have been proposed to achieve this goal.

\section{A Return to Formalities?}

Many suggested that a return to formalities might ease the weaknesses of the current copyright regime. According to these proposals, published works would not be copyrighted, unless the authors comply with some simple, cheap and nondiscriminatory formalities. ${ }^{55}$ The idea of a registration system for creative works through global online copyright registries is increasingly gaining momentum. ${ }^{56}$ Formalities might become an opportunity for creativity in the digital era as technology overcame most discriminatory hurdles that persuaded the international community to abolish them in the analog world. ${ }^{57} \mathrm{~A}$ return to formalities would endorse a user-centered approach to copyright policy that promotes UGC creativity. A modern registration system may enrich the public domain, enhance access and reuse, and avoid transaction costs burdening digital creativity. Registration could be a precondition for protection. Alternatively, registration might at least be required as a precondition of extension of protection. ${ }^{58}$

\footnotetext{
${ }^{53}$ See Hans Kelsen, General Theory of Law And State (Harvard U. Press 1949).

${ }^{54}$ Cohen, supra note 40 , at 374.

55 See, e.g., Christopher Sprigman, Reform(aliz)ing Copyright, 57 STAN. L. REV. 485 (2004) (proposing an optional registration system that subjects unregistered works to a default licence under which the use of the work would trigger only a modest statutory royalty liability); LAWRENCE LESSIG, Free Culture: How Big Media Uses Technology AND the LAW to Lock Down Culture And Control Creativity 140 (Penguin 2004); Lawrence Lessig, The Future of Ideas: The Fate of The Commons in a Connected World (Vintage Books 2002); Lewis Hyde, How to Reform Copyright, THE CHRONICLE, October 9, 2011, http://chronicle.com/article/ How-to-ReformCopyright/129280;

56 See ANDREw Gowers, Gowers REVIEW OF INTEllectuAl Property (HM Treasury, November 2006), at Recommendation 14b (endorsing the establishment of a voluntary register of copyright).
}

57 See Stef van Gompel, Formalities in the digital era: an obstacle or opportunity?, in GLOBAL COPYRIGHT: THREE HundRED YEARS SINCE THE STATUTE OF ANNE, FROM 1709 TO CYBERSPACE 395424 (Lionel Bently, Uma Suthersanen and Paul Torremans eds., Edward Elgar 2010) (arguing that the pre-digital objections against copyright formalities cannot be sustained in the digital era); see also Takeshi Hishinuma, The Scope of Formalities in International Copyright Law in a Digital Context, in Global Copyright: Three Hundred YeArs Since the STATUTE of ANNE, From 1709 TO CYBERSPACE 460-467 (Lionel Bently, Uma Suthersanen and Paul Torremans eds., Edward Elgar 2010).

${ }^{58}$ See Lawrence Lessig, Recognizing the Fight We're In, keynote speech delivered at the Open Rights Group Conference, London, UK (March 24, 2012), at 36:40-38:28, available at http://vimeo.com/39188615, (proposing the reintroduction of formalities at least to secure extensions of copyright, if legislators decide to introduce them). 
In Making Copyright Fit for the Digital Agenda, Marco Ricolfi's designed an alternative copyright default rule, coupled with the implementation of a formality and registration system, that goes by the name of Copyright $2.0 .^{59}$ Other scholars, such as Lessig, made also similar proposals. ${ }^{60}$ In Ricolfi's Copyright 2.0, traditional copyright, or Copyright 1.0, is still available. Copyright 1.0 must be claimed by the creator at the onset, for example by inserting a copyright notice before the first publication of a work. At certain conditions, the Copyright 1.0 notice could also be added after the first publication, possibly during a specified and short grace period. The Copyright 1.0 protection given by the original notice is deemed withdrawn after a specified brief period of time, unless an extension period is formally requested through an Internet based renewal and registration procedure, whose registration data will be accessible online. If no notice is given - or no extension is soughtCopyright 2.0 applies, providing creators with the right to attribution.

\section{Mandatory Exceptions for UGC}

As Cohen has argued, a user-centered approach to traditional copyright doctrines "would understand "publicness" as hinging importantly on a resource's practical accessibility, and would observe that copyrighted cultural goods, and especially mass commercial culture, comprise an increasingly large fraction of the public experience of culture." ${ }^{\prime 61}$ In this respect, mandatory exceptions have been claimed as a solution for user-generated content, together with the use of informal copyright practices. ${ }^{62}$

Proposals have been made for introducing an exception for transformative use in user-generated works. ${ }^{63}$ Canada introduced a specific exception to this effect. The

\footnotetext{
${ }^{59}$ See Marco Ricolfi, Making Copyright Fit for the Digital Agenda, in IL DiRITTO D’AUTORE 359-372 (2011); see also Marco Ricolfi, Copyright Policies for Digital Libraries in the Context of the i2010 Strategy, paper presented at the 1st COMMUNIA Conference (July 1, 2008), at 6, available at http://www.communia-project.eu/node/110.
}

${ }^{60}$ See LaWrence Lessig, Remix: Making ART AND Commerce Thrive IN THE Hybrid ECONOMY 253-265 (Bloomsbury 2008) (proposing different routes for professional, remix and amateur authors, registries, and the re-introductuìion of formalities and an opt-in system).

${ }^{61}$ Cohen, supra note 40 , at 368.

${ }^{62}$ See, e.g., Edward Lee, Warming Up to User-Generated Content, 2008 U. ILL. L. REv. 1459, 1462 (2008) (noting that "informal copyright practices-i.e., practices that are not authorized by formal copyright licenses but whose legality falls within a gray area of copyright law-effectively serve as important gap fillers in our copyright system"); Steven A. Hetcher, Using Social Norms to Regulate Fan Fiction and Remix Culture, 157 U. PA. L. REV. 1869 (2009).

${ }^{63}$ See Warren B. Chik, Paying it Forward: The Case for a Specific Statutory Limitation on Exclusive Rights for User-Generated Content Under Copyright Law, 11 J. MARSHALL REV. INTELL. PROP. L. 240 (2011); Daniel Gervais, The Tangled Web of UGC: Making Copyright Sense of User-Generated Content, 11 VAND. J. EnT. \& TECH. L. 841, 861-869 (2009); Debora Halbert, Mass Culture and the Culture of the Masses: A Manifesto for User-Generated Rights, 11 VAND. J. ENT. \& TECH. L. 921, 934-953 (2009); Mary W. S. Wong, "Transformative" User-Generated Content in Copyright Law: Infringing Derivative Works or Fair Use?, 11 VAND. J. ENT. \& TECH. L. 1075 (2009). 
Canadian copyright law now allows the use of a protected work-which has been published or otherwise made available to the public - in the creation of a new work, if the use is done solely for non-commercial purposes and does not have substantial adverse effects on the potential market for the original work. ${ }^{64}$ Likewise, the U.S. Copyright Office rulemaking on the DMCA anti-circumvention provisions recently introduced an exception for the use of movie clips for transformative, noncommercial works - making vidding easier-and the European institutions and stakeholders have been recently discussing a specific exception for UGC. ${ }^{65}$

Also, general fair use exception clauses, if properly construed, may prove effective to give UGC creators some breathing space. In particular, recent U.S. case law protects UGC creators from bogus DMCA takedown notices in cases of blatant misrepresentation of fair use defences by copyright holders. In Lenz v. Universal Music, the 9th Circuit ruled that "the statute requires copyright holders to consider fair use before sending takedown notification." 66 The Court also recognised the possible applicability of section 512(f) of the DMCA that allows for the recognition of damages in case of proved bad-faith, which would occur if the copyright holder did not consider fair use or paid "lip service to the consideration of fair use by claiming it formed a good faith belief when there is evidence to the contrary."67

\section{REIMAGINING ACCESS}

Mostly driven by scholarly efforts, an Access to Knowledge (A2K) Movement, an Open Access Publishing (OAP) Movement, a Public Domain Project and Cultural Environmentalism sought to re-define the hierarchy of priorities embedded in the traditional politics of intellectual property. They promoted a vision that tips the

64 See An Act to amend the Copyright Act, 2010, Bill C-32 (Can.), Art. 22, available at http://www.parl.gc. ca/HousePublications/Publication.aspx?Docid=4580265\&file=4; see also Peter Yu, Can the Canadian UGC Exception Be Transplanted Abroad?, 26 InTELL. PROP. J. 177 (2014) (discussing also a Hong Kong proposal for a UGC exception);

65 See United States Copyright Office, Rulemaking on Exemptions from Prohibition on Circumvention of Technological Measures that Control Access to Copyrighted Works (July 26, 2010), available at http://www.copyright.gov/1201/2010; Commission, Report on the Responses to the Public Consultation on the Review of the EU Copyright Rules (July 2014), at 68 (EU), available at https://www.yumpu.com/en/document/view/30151098/zzeia/69 (noting that respondents often favour a legislative intervention, which could be done "by making relevant existing exceptions (parody, quotation and incidental use and private copying are mentioned) mandatory across all Member States or by introducing a new exception to cover transformative uses"); see also Commission Communication on Content in the Digital Single Market, at 3-4, COM(2012) 789 final (December 18, 2012) (EU) (proposing micro-licensing arrangements that were later sidelined).

${ }^{66}$ Stephanie Lenz v. Universal Music Corp., 5:07-cv-03783-JF (9 ${ }^{\text {th }}$ Cir. 2015), at 5.

${ }^{67} \mathrm{Id}$., at 17-18 (noting also that there's no liability under $\S 512(\mathrm{f})$ ), “[i]f, however, a copyright holder forms a subjective good faith belief the allegedly infringing material does not constitute fair use"). 
balance in favour of the access factor of the copyright paradox. ${ }^{68}$ Apparently, all these movement find their justification in a cultural theory approach to intellectual property policy, seeking enhanced "distributive justice" beyond the progressive but market-based approach of more traditional welfare and utilitarian theories. ${ }^{69}$ Supposedly - once again - creativity would thrive through the power of imitation, open access, easier reuse and technological innovation would serve as a prism multiplying social value.

\section{Access to Knowledge (A2K)}

As Nelson Mandela once noted, "eliminating the distinction between the information-rich and information-poor is . . . critical to eliminating economic and other inequalities between North and South, and to improving the life of all humanity." ${ }^{70}$ Since a 1961 Brazilian draft resolution, ${ }^{71}$ Access to Knowledge (A2K) has become a question of major international concern as "access to learning and knowledge [are] key elements towards the improvement of the situation of under privileged countries." 72 In addition, copyright expansion, cultural appropriation, and dysfunctional access to scientific and patented knowledge do heighten the NorthSouth cultural divide. As a consequence, A2K emerged as a globalized movement that "takes concerns with copyright law and other regulations that affect knowledge" and aims at promoting redistribution of informational resources in favor of minorities and the Global South ${ }^{73}$ In this sense, the A2K movement might be construed as an umbrella notion under which other endeavours, such the OAP Movement or the

${ }^{68}$ See Christophe Geiger, Copyright as an Access Right: Securing Cultural Participation through the Protection of Creators' Interests, in WHAT IF WE COULD REIMAGINE COPYRIGHT? (Rebecca Giblin and Kimberlee Weatherall eds., ANU Press, 2017) (discussing the notion of copyright as an access right and proposing solutions to enhance access within the copyright paradox).

69 See William Fisher, Theories of Intellectual Property, in NEW ESSAYS IN THE LEGAL AND POLITICAL THEORY OF PROPERTY 168-199 (Stephen Munzer ed., CUP 2001).

${ }^{70}$ Nelson Mandela, speech delivered at TELECOM 95, Geneva (October 3, 1995) quoted in ERNEST J. WILSON, III, THE INFORMATION REVOLUTION AND DEVELOPING COUNTRIES 1 (2004).

71 See Graham DutField and Uma Suthersanen, Global InTEllectual Property LAW 277 (Edward Elgar 2008).

72 World Intellectual Property Organization [WIPO], Draft Report of the Provisional Committee on Proposals Related to a WIPO Development Agenda of the World Intellectual Property Organization 6 (African Group Statement).

${ }^{73}$ Consumer Project on Technology, Access to Knowledge Movement, http://www.cptech.org/a2k; see also ACCESS TO KNOWLEDGE IN THE AgE OF INTElleCtUAL PROPERTY (Gaëlle Krikorian and Amy Kapczynski eds., Zone Books 2011); ACCESs TO KnOwledge IN AFrICA: ThE Role OF COPYRIGHT (Chris Armstrong, Jeremy de Beer, Dick Kawooya, Achal Prabhala, and Tobias Schonwetter eds., UCT Press 2010); Amy Kapczynski, The Access to Knowledge Mobilization and The New Politics of Intellectual Property, 117 YALE L. J. 804 (2008). 
Public Domain Project, can be re-comprehended, in pursuit of the establishment of a cultural theory approach to policies for creativity.

International working projects have tried to address the requests of the $\mathrm{A} 2 \mathrm{~K}$ movement under the framework of Article 27 of the Universal Declaration of Human Rights, stating that "everyone has the right freely to participate in the cultural life of the community, to enjoy the arts and to share in scientific advancement and its benefits." 74 As part of the discussions leading to the adoption of the WIPO Development Agenda, ${ }^{75}$ activists produced a document to start negotiations on a Treaty on Access to Knowledge. ${ }^{76}$ The proposed treaty is based on the core idea that "restrictions on access ought to be the exception, not the other way around," and that "both subject matter exclusions from, and exceptions and limitations to, intellectual property protection standards are mandatory rather than permissive." ${ }^{.77}$ Consensus on the A2K Treaty does appear hard to reach; however, a narrow version was signed in Marrakesh in 2013 to promote the use of protected works by disabled persons. ${ }^{78}$

\section{Open Access Publishing (OAP)}

Although international agreement on an A2K Treaty may be hard to reach, grassroots movements spearheaded similar goals through different routes. A quest for open access to academic knowledge occupied the recent agenda of a global network of institutions and stakeholders. At CERN in Geneva, Lawrence Lessig reminded the audience of scientists and researchers that most scientific knowledge is locked away for the general public and can only be accessed by professors and students in a university setting. Lessig pungently made the point that "if you are a member of the knowledge elite, then there is free access, but for the rest of the world, not so much [. ..] publisher restrictions do not achieve the objective of enlightenment, but rather the reality of "elite-nment." 79 Other authors have reinforced this point. John Willinsky, for example, suggested that, as its key contribution, open access publishing (OAP)

\footnotetext{
${ }^{74}$ See Universal Declaration of Human Rights, G.A. Res. 217A (III), U.N. Doc. A/810 at 71 (1948), Art. 27.

75 See Development Agenda for WIPO, http://www.wipo.int/ip-development/en/agenda.

${ }^{76}$ See Proposed World Intellectual Property Organization Treaty on Access to Knowledge (May 9, 2005) (Draft), available at www.cptech.org/a2k/a2k treaty may9.pdf.

${ }^{77}$ Laurence R. Helfer, Toward a Human Rights Framework for Intellectual Property, 40 U.C. DAVIS L. REV. 971, 1013 (2007).

${ }^{78}$ See Marrakesh Treaty to Facilitate Access to Published Works for Persons Who Are Blind, Visually Impaired or Otherwise Print Disabled (July 27, 2013).

${ }^{79}$ Lawrence Lessing, The Architecture of Access to Scientific Knowledge: Just How Badly we Have Messed This Up (speech delivered at CERN Colloquium and Library Science Talk) (April 18, 2011), available at http://cdsweb.cern.ch/record/1345337; see also Lawrence Lessig, Recognizing the Fight We're In, keynote speech delivered at the Open Rights Group Conference, London, UK (March 24, 2012), available at http://vimeo.com/39188615.
} 
models may move "knowledge from the closed cloisters of privileged, well-endowed universities to institutions worldwide." $" 80$

The dramatic increase in prices for journals and publisher restrictions to the reuse of information inspired-and motivated - the OAP movement in scholarly publishing. ${ }^{81}$ The academics' reaction against the 'cost of knowledge' - also known as the serial crisis - is on the rise, especially against the practice of charging 'exorbitantly high prices for [ . . . ] journals' and of 'sell[ing] journals in very large bundles'. ${ }^{82}$ George Monbiot stressed the unfairness of the academic publishing system by noting, with specific reference to publishers such as Elsevier, Springer, or Wiley-Blackwell:

[w]hat we see here is pure rentier capitalism: monopolising a public resource then charging exorbitant fees to use it. Another term for it is economic parasitism. To obtain the knowledge for which we have already paid, we must surrender our feu to the lairds of learning. ${ }^{83}$

According to Monbiot, this economic parasitism results from a monopoly over content that the academic publishers do not create and do not pay for. ${ }^{84}$ Researchers, hoping to publish with reputable journals, surrender their copyrights for free. Most of the times, the production of that very content-now monopolized by the academic publishers-was funded by the public, through government research grants and academic incomes. This led some authors to discuss the opportunity of abolishing copyright for academic works all together. ${ }^{85}$ From the ancient proverbial idea of scientia donum dei est unde vendi non potest to the emergence of the notion of 'open science', the normative structure of science presents an unresolvable tension with the

80 John Willinsky, The ACCESS PRINCIPLE: The CASE FOR OPen ACCESS to Research AND SCHOLARSHIP 33 (MIT PRESS 2006).

${ }^{81} \mathrm{See}$ GianCARlo F. Frosio, Open ACCESS PUblishing: A Literature ReVIEW (study prepared for the RCUK Centre for Copyright and New Business Models in the Creative Economy) (2014), available at http://www.create.ac.uk/publications/open-access-publishing-a-literature-review (providing a book length overview of the OAP movement and several open access initiatives and projects, economics of academic publishing and copyrioght implications, OAP business models, and OAP policy initiatieves).

82 See The Cost of Knowledge, Researchers Taking a Stand against Elsevier, http://thecostofknowledge.com; The Price of Information: Academics are Starting to Boycott a Big Publisher of Journals, THE ECONOMIST, February 4 2012, http://www.economist.com/node/21545974; see also Eyal Amiran, The Open Access Debate, 18(1/2) SYMPLOKE 251 (2011) (reporting several other example of these reactions and boycotts).

${ }^{83}$ See George Monbiot, Academic Publishers Make Murdoch Look like a Socialist, THE GuARDIAN, August 29, 2011, http://www.guardian.co.uk/commentisfree/2011/aug/29/academic-publishersmurdoch-socialist.

${ }^{84} I d$.

${ }^{85}$ See Steven Shavell, Should Copyright of Academic Works Be Abolished? 2 J. LEGAL ANALYSIS 301, 301-358 (2010). 
exclusive and monopolistic structure of intellectual property entitlements. Merton powerfully emphasized the contrast between the ethos of science and intellectual property monopoly rights:

"Communism," in the nontechnical and extended sense of common ownership of goods, is a second integral element of the scientific ethos. The substantive findings of science are a product of social collaboration and are assigned to the community. They constitute a common heritage in which the equity of the individual producer is severely limited. An eponymous law or theory does not enter into the exclusive possession of the discoverer and his heirs, nor do the mores bestow upon them special rights of use and disposition. Property rights in science are whittled down to a bare minimum by the rationale of the scientific ethic. The scientist's claim to "his" intellectual "property" is limited to that of recognition and esteem which, if the institution functions with a modicum of efficiency, is roughly commensurate with the significance of the increments brought to the common fund of knowledge. ${ }^{86}$

The Berlin Conferences gave a major propulsion to OA. Most significantly, they resulted in the Berlin Declaration on Open Access to Knowledge in the Sciences and Humanities, including the goal of disseminating knowledge through the open access paradigm via the Internet. ${ }^{87}$ OAP refers to free and unrestricted world-wide electronic distribution and availability of peer-reviewed journal literature. The Budapest Open Access Initiative (OAI) uses a definition that includes free reuse and redistribution of "open access" material by anyone. ${ }^{88}$ According to Peter Suber, the de facto spokesperson of the OAP movement,

[o]pen access (OA) is free online access [. . . OA literature is not only free of charge to everyone with an internet connection, but free of most copyright and licensing restrictions. OA literature is barrier-free literature produced by removing the price barriers and permission barriers that block access and limit usage of most conventionally published literature, whether in print or online. ${ }^{89}$

OAP has been growing at staggering rate since 2001, when the OAI was first promoted. There are now almost ten thousand open access journals. ${ }^{90}$ OAP

${ }^{86}$ Robert K Merton, The Normative Structure of Science, in THE Sociology OF SCIENCE: THEORETICAL AND EMPIRICAL INVESTIGATIONS 273 (U. Chicago Press 1979) (1942); see also James Boyle, Mertonianism Unbound, Imagining Free, Decentralized Access to Most Cultural and Scientific Material, in Understanding KnOWLedge as a Commons: From TheOry to Practice 124 (Charlotte Hess and Elinor Ostrom eds., MIT Press 2006).

${ }^{87}$ See Berlin Declaration on Open Access to Knowledge in the Sciences and Humanities (October 22, 2003), Berlin Conference, Berlin, October 20-22, 2003, available at http://oa.mpg.de/lang/enuk/berlin-prozess/berliner-erklarung.

88 Budapest Open Access Initiative, Budapest, Hungary, February 14, 2002, http://www.soros.org/open access/index.shtml

${ }^{89}$ Peter Suber, Creating an Intellectual Commons Through Open Access, in UNDERSTANDING Knowledge as a Commons: From Theory to Practice 171 (Charlotte Hess and Elinor Ostrom eds., MIT Press 2006).

${ }^{90}$ See DOAJ, Directory of Open Access Journals, http://www.doaj.org. 
arrangements have been increasingly endorsed by governmental institutions, ${ }^{91}$ in light of the fact that economic studies shown a positive net value of OAP models when compared to other publishing models. ${ }^{92}$ The European Commission, for example, plans to make OAP the norm for research receiving founding from its Horizon 2020 research programme. ${ }^{93}$ As part of its Innovation and Research Strategy for Growth, the UK government has announced that all publicly funded scientific research must be published in OA journals. ${ }^{94}$ In the US, the Consolidated Appropriations Act of $2008^{95}$ instituted an OA mandate for research projects funded by the NIH. ${ }^{96}$ Together with research articles, data, teaching materials, and the like, the importance of open access models extends also to books. Millions of historic volumes are now openly accessible from various digitization projects such as Europeana, Google Books, or Hathi.

Richard Nelson argued that "the key to assuring that a large portion of what comes out of future scientific research will be placed in the commons is staunch defense of the commons by universities." 97 Nelson continues by arguing that if universities "have policies of laying their research results largely open, most of science will continue to be in the commons." 98 The role of universities in the OA and OAP movement is critical. Willinsky advocated the idea that universities and scholars have a responsibility to make their work available OA globally by referring to an

\footnotetext{
91 See Frosio, supra note 81, at 163-180.

92 See JOHn Houghton, OPEn ACCESS - WhAT ARE THE ECONOMIC BENEFITS? A COMPARISON OF THE UNITED KingDOM, NETHERLANDS AND DENMARK (June 23, 2009) (report prepared for Knowledge Exchange) (showing that adopting an open access model to scholarly publications could lead to annual savings of around $€ 70$ million in Denmark, $€ 133$ million in the Netherlands and $€ 480$ million in the United Kingdom); JOHN HOUGHTON WITH BRUCE RASMUSSEN AND PETER SHEEHAN, ECONOMIC AND SOCIAL RETURNS ON INVESTMENT IN OPEN ARCHIVING PUBLICLY FUNDED RESEARCH OUTPUTS (July 2010) (report prepared for The Scholarly Publishing \& Academic Resources Coalition) (concluding that free access to U.S. taxpayer-funded research papers could yield \$1 billion in benefits)

93 See Horizon 2000, The Framework Programme for Research and Education, http://ec.eur opa.eu/research/horizon2020/index en. cfm.
}

${ }^{94}$ See InNOVATION AND RESEARCH STRATEGY FOR GROWTH 76-78 (prepared by the Department for Business Innovation and Skills) (December 2011); see also WORKING GROUP ON EXPANDING ACCESS to Published Research Findings, ACCessibility, Sustainability, Excellence: How tO EXPAND ACCESS TO RESEARCH PUBLICATIONS (FINCH REPORT) (June 2012).

95 See Consolidated Appropriations Act of 2008 HR 2764.

96 See National Institutes of Health, Revised Policy on Enhancing Public Access to Archived Publications Resulting from NIH-Funded Research, http:/grants.nih.gov/grants/guide/noticefiles/NOT-OD-08-033.html.

${ }^{97}$ Richard R Nelson, The Market Economy, and the Scientific Commons, 33 RESEARCH POLICY 455, 467 (2004).

${ }^{98} I d$. 
"access principle." 99 The challenge ahead of the OAP movement is to turn university environments - and the knowledge produced within - into a more easily and freely accessible public good, perhaps better integrating the OAP movement with Open University and Open Learning. Seeking to reap the full value that OA can yield in the digital environment, Jerome Reichman and Paul Uhlir proposed a model of Open Knowledge Environments (OKEs) for digitally networked scientific communication. ${ }^{100}$ OKEs would "bring the scholarly communication function back into the universities" through "the development of interactive portals focused on knowledge production and on collaborative research and educational opportunities in specific thematic areas." 101

\section{Digital Libraries}

OKEs might also serve the goal of open-access by contributing to reshape the role of libraries. Digital libraries - and the long-term goal of digitizing and making available online the entire corpus of human knowledge - stand as a critical milestone for the future development of the information society. They become essential to boost citizens' cultural empowerment and democratization, which hopefully the digital interconnected society will bring about. OAP and OEKs should make easier the creation of digital public libraries, possibly making the dream of the Digital Library of Alexandria come true. ${ }^{102}$

The creation of a public digital library versus the private model offered by Google has been widely discussed. Robert Darnton - the Harvard über-librarian-repeatedly called for the creation of a national digital library, despite acknowledging the difficulties of a public effort to digitize and connect all material into a single resource. ${ }^{103}$ Europeana - the EU digital library - is a key aspect the Digital Agenda of the European Union. ${ }^{104}$ Digital public libraries should build upon the many

\footnotetext{
99 WiLlinsky, supra note 80, at xii; see also PETER SUBER, OPEN ACCESS (MIT Press 2012) (discussing the emergence of this principle).

100 See Jerome H. REICHMAN, TOM DEDEURWAERdERE, AND PAUl F. UhLIR, Governing DigITALLY InTEGRATED GENETIC RESOURCES, DATA, AND LiTERATURE: GLOBAL INTELlECTUAL PROPERTY Strategies For A REDESIGNED Microbial RESEARCH COMMONS (Cambridge U. Press, 2016).

${ }^{101}$ Paul F. Uhlir, Revolution and Evolution in Scientific Communication: Moving from Restricted Dissemination of Publicly-Funded Knowledge to Open Knowledge Environment, speech delivered at the $2^{\text {nd }}$ COMMUNIA Conference (June 28, 2009).

${ }^{102}$ Cf. Giancarlo F. Frosio, Google Books Rejected: Taking the Orphans to the Digital Public Library of Alexandria, 28 SANTA ClaRA High TECH. L. J. 81 (2011).

${ }^{103}$ Robert Darnton, Can we Create a National Digital Library?, THE NEW YORK REVIEW OF BoOKS, October 28, 2010, http://www.nybooks.com/articles/archives/2010/oct/28/can-we-create-nationaldigital-library.

${ }^{104}$ See Commission Communication, Europe 2020: A Strategy for Smart, Sustainable and Inclusive Growth, COM(2010) 2020 (March 3, 2010); see also European Parliament and Council Directive 2012/28/EU on Certain Permitted Uses of Orphan Works, 2012 O.J. (L 299)5 (October 25, 2012)
} 
ongoing non-profit digitization and digital preservation projects, such as the Library of Congress American Memory Project, the Online Books Page, the Hathi Trust Digital Library, Project Gutenberg, and the Million Books Project. Additionally, non-proprietary and open library projects extend beyond book repositories, such as the Internet Archive or the International Music Score Library Project. A public digital library should connect all these projects and offer a single access portal, together with a common policy for access and re-use. ${ }^{105} \mathrm{~A}$ World Digital Public Library that integrates OKEs will push forth the rediscovery of currently unused or inaccessible works, open up the riches of knowledge in formats that are accessible to persons with disabilities and, empower democratization by favoring access regardless of market power. ${ }^{106}$ However,

libraries are increasingly consuming significant shares of their knowledge goods from globalized publishers according to the contractual and technological protection measures that these publishers impose on their digital content. Thus there is an unavoidable movement of enclosure regarding the provision of knowledge through libraries, all in a manner that practically compels libraries to take part in the privatization of knowledge supply and distribution. ${ }^{107}$

Therefore, the road to global access to knowledge is to provide digital libraries with a better framework to support their independence from commodification of knowledge. Nellie Kroes warns against the welfare loss of the immense cultural riches unveiled by digitization, nevertheless locked behind the intricacies of an outdated copyright model.

Think of the treasures that are kept from the public because we can't identify the right-holders of certain works of art. These "orphan works" are stuck in the digital darkness when they could be on digital display for future generations. It is time for this dysfunction to end. ${ }^{108}$

A return to formalities, registries and data collection might effectively ease the orphan works problem. ${ }^{109}$ Today, technology enables the creation of global digital

(enabling the use of orphan works after diligent search for public libraries digitization projects); Case C-117/13, Technische Universität Darmstadt v Eugen Ulmer KG, 2014 E.C.D.R. 23 (September 11, 2013) (stating that European libraries may digitize books in their collection without permission from the rightholders with caveats).

105 See Berkman Center Announces Digital Public Library Planning Initiative, December 13, 2010, http://cyber.law.harvard.edu/newsroom/digital_public library.

106 See, for additional considerations on the creation of a World Digital Public Library, Frosio, supra note 102, 106-117 (2011).

${ }^{107}$ Pessach Guy, The Role of Libraries in A2K: Taking Stock and Looking Ahead, 2007 MiCH. ST. L. REV. 257 (2007).

${ }^{108}$ Nellie Kroes, Ending Fragmentation of the Digital Single Market, speech delivered at the Business for New Europe event, London, SPEECH/11/70 (February 7, 2010).

${ }^{109}$ See, discussing copyright registers, Tanya Aplin, A Global Digital Register for the Preservation and Access to Cultural Heritage: Problems, Challenges and Possibilities, in COPYRIGHT AND 
repositories that ensure the integrity of digital works, render filings user-friendly and inexpensive, and enable searches on the status of any creative work. ${ }^{110}$ Measures to improve the provision of rights management information range from encouraging digital content metadata tagging, to promoting the use of creative commons-like licenses, and encouraging the voluntary registration of rights ownership information in specifically designed databases. ${ }^{111}$ Many projects aim at increasing the supply of rights management information to the public, merging unique sources of rights information, and establishing specific databases for orphan works. Notably, the EU mandated project ARROW includes national libraries, publishers, writers' organizations and collective management organizations and aspires to find ways of identifying rightholders, determining and clearing rights, and possibly confirming the public domain status of a work. ${ }^{112}$

The implementation of a diligent search system and a mandatory exception as a defense to copyright infringement for the use of orphan works has been advocated in multiple jurisdictions. This arrangement implies that a bona fide/good faith user must conduct a diligent search prior to the use of the work to avoid liability. In the United States, proposals have been made following Copyright Office's recommendations but never adopted into law. ${ }^{113}$ The High-Level Expert Group on the European Digital Libraries Initiative made similar recommendations:

Member States are encouraged to establish a mechanism to enable the use of such works for non-commercial and commercial purposes, against agreed terms and remuneration, when applicable, if diligent search in the country of origin prior to the

Cultural Heritage: Preservation and Access to Works in a Digital World 3-27 (Estelle Derclaye ed., Edward Elgar 2010); Caroline Colin, Registers, Databases and Orphan Works, in Copyright AND Cultural Heritage, supra, at 28-50; Steven Hetcher, A Central Register of Copyrightable Works: a U.S. Perspective, in COPYRIGHT AND Cultural Heritage, supra, at 156176.

${ }^{110}$ See Gowers, supra note 56, at Recommendation 14b (endorsing the establishment of a voluntary register of copyright).

${ }^{111}$ See van Gompel, supra note 57, at 11-14 (noting that only voluntary supply of information would be compliant with the no-formalities prescription of the Berne Convention).

${ }^{112}$ See Accessible Registries of Rights Information and Orphan Works [ARROW], http://www.arrownet.eu (creating registries of rights information and orphan works); BARBARA STRATTON, SEEKING New LANDSCAPES. A Rights Clearance Study IN THE CONTEXT OF MASS Digitization of 140 BOOKS PUBLISHED BETWEEN 1870 AND 2010 5, 35-36 (British Library 2011)_(showning that in contrast to the average four hours per book to undertake a diligent search, "the use of the ARROW system took less than 5 minutes per tile to upload the catalogue records and check the results").

${ }^{113}$ See The Register OF COPYRIGHTS, REPORT ON ORPHAN WORKS 95 (2006); see also Christian L. Castle and Amy E. Mitchell, Unhand That Orphan: Evolving Orphan Works Solutions Require New Analysis, 27-SPG ENT. \& SPORTS L. 1 (2009). 
use of the works has been performed in trying to identify the work and/or locate the rightholders. ${ }^{114}$

Partially endorsing these principles, EU Directive on certain permitted uses of orphan works has adopted a diligent search standard for public digitization projects across Europe. ${ }^{115}$ Broder solutions have been discussed. A British Screen Advisory Committee (BSAC)'s proposal would set up a compensatory liability regime based on 'best endeavours' to locate the copyright owner of a work. ${ }^{116}$ If a rights owner emerges, he is entitled to claim a 'reasonable royalty' agreed upon by negotiationor established by a third-party - rather than sue for infringement. Use of the work that has been integrated or transformed into a derivative work should be allowed to continue upon payment of a reasonable royalty and sufficient attribution. Slightly modified versions of this model have been already implemented elsewhere. For example, Canada established a compulsory licensing system based on diligent searches to use orphan works. ${ }^{117}$ Upon showing of a serious search for the rightsholder, an administrative body can issue a non-exclusive license-limited to Canada - to use orphan works. ${ }^{118}$

Finally, Extended Collective Licenses (ECL) have become a policy option in several jurisdictions to tackle the orphan works problem within digitization projects. ${ }^{119}$ They are applied in various sectors in Denmark, Finland, Norway,

114 i2010 European Digital Libraries Initiative, High level Expert Group on Digital Libraries, Final Report, Digital Libraries: Recommendations and Challenges for the Future (December, 2009), available at http://ec.europa.eu/info rmation_society/activities/digital_libraries/doc/hleg/reports/hlg_final_report09.pdf.

115 See Orphan Works Directive, supra note 104; see also i2010 European Digital Libraries Initiative, High level Expert Group on Digital Libraries, Final Report, Digital Libraries: Recommendations and Challenges for the Future (December, 2009), available at http://ec.europa.eu/info rmation_society/activities/digital_libraries/doc/hleg/reports/hlg_final_report09.pdf.

116 See British SCREEN AdvisOry COUNCIL, COPYRIGHT AND ORPHAN WORKS (August 31, 2006) (paper prepared for the Gowers Review).

117 See Canadian Copyright Act, Art. 77 (Can.).

${ }^{118}$ Id.; see Stef van Gompel, Unlocking the Potential of Pre-Existing Content: How to Address the Issue of Orphan Works in Europe?, 38 InT’L REV. InTEL. PROP. COMP. L. 669 (2007).

119 See Jia Wang, Should China Adopt an Extended Licensing System to Facilitate Collective Copyright Administration: Preliminary Thoughts, 32 EUR. INTELL. ProP. REV. 283 (2010); MARCO Ciurcina, JuAn Carlos De martin, Thomas MARgoni, Federico Morando, AND Marco Ricolfi, Creatività Remunerata, Conoscenza Liberata: File Sharing e Licenze Collettive Estese [REMunERATING CREATIVITY, FREEING KNOWledge: FILE-Sharing AND EXTENDED COLlECTIVE LICENCES] (March 15, 2009) (position paper prepared for the NEXA Center for Internet and Society); JOHAN AXHAMn AND LuCIE GuIBAult, Cross-Border EXTENDED Collective LiCENSING: A SOLUTION TO ONLINE DisSEMINATION OF EUROPE'S CULTURAL HERITAGE? (final report prepared for EuropeanaConnect, IViR, August 2011). 
Sweden and Iceland ${ }^{120}$ and included in a recent EU draft directive for the use of outof-commerce works by cultural heritage institutions. ${ }^{121}$ The system combines the voluntary transfer of rights from rightholders to a substantially representative collective society with the legal extension of the collective agreement to third parties who are not members of the collective society. A user may obtain a licence to use all the works included in a certain category. With the exception of the rightholders claiming individual remuneration or opting out from the system, the ECL automatically applies to all domestic, foreign, traceable or untraceable rightsowners. Actually - as seen also in the Google books case - courts have expressed hesitations in endorsing the ECL opt-out mechanism. In Soulier, the ECJ declared EU law uncompliant a French law endorsing an ECL mechanism to authorise the reproduction and digital representation of out-of-print 20th century books. ${ }^{122}$ According to the ECJ, EU law provides authors - not collecting societies-with the right to authorise the reproduction and communication to the public of their works. ${ }^{123}$ The Soulier decision might have far-reaching effects for the EU directive proposaland more generally for all national ECL systems that might be incompatible with EU law.

\section{Reimagining a Positive Public Domain}

The increasing enclosure of the public domain has contributed to the crisis of acceptance in which copyright law is fallen. As Jessica Litman noted, "a vigorous public domain is a crucial buttress to the copyright system; without the public domain, it might be impossible to tolerate copyright at all." ${ }^{124}$ The emphasis over the importance of the public domain has gained momentum together with the rise of the networked information economy. The emergence and recognition of the public domain, the development of a public domain project and the advent of cultural environmentalism coalesce also to "resist the resistance." In this respect, Daniel Drache noted that "the emergence of the public domain and public goods in the

\footnotetext{
${ }^{120}$ See, e.g., Zijian Zhang, Transplantation of an Extended Collective Licensing System - Lessons from Denmark, 47(6) IIC 640 (2016).

${ }^{121}$ See Proposal for a Directive of the European Parliament and of the Council on Copyright in the Digital Single Market, COM(2016) 593 final (September 14, 2016), Art. 7.

122 See Marc Soulier Sara Doke v Ministre de la Culture et de la Communication Premier minister, C301/15 (ECJ, November 16, 2016) (European Union); see also LOI n 2012-287 du 1er mars 2012 relative à l'exploitation numérique des livres indisponibles du XXe siècle, available at https://www.legifrance.gouv.fr/eli/loi/2012/3/1/2012-287/jo/texte.

${ }^{123}$ See Council Directive 2001/29/EC on the harmonisation of certain aspects of copyright and related rights in the information society, 2001 O.J. (L 167) 10 (22 May 2001) Art. 2(a) and 3(1).

124 Jessica Litman, The Public Domain, 39 EMORY L. J. 965, 977 (1990).
} 
globalized society have increasingly troubled the future prospects of "market fundamentalism." $" 125$

In early copyright law, there was no positive term to affirmatively refer to the public domain, though terms like publici juris or propriété publique had been employed by $18^{\text {th }}$ century jurists. ${ }^{126}$ Nonetheless, the fact of the public domain was recognized. Soon, the idea of the public domain evolved into a "discourse of the public domain - that is, the construction of a legal language to talk about public rights in writings." ${ }^{127}$ Historically, the term public domain was firstly employed in France by the mid- $19^{\text {th }}$ century-and slightly later in England and the United States - to mean the expiration of copyright. ${ }^{128}$ Traditionally, the public domain has been defined in relation to copyright as the opposite of property, as the "other side of the coin of copyright" that "is best defined in negative terms". ${ }^{129}$ This traditional definition regarded the public domain as a "wasteland of undeserving detritus" and did not "worry about 'threats' to this domain any more than [it] would worry about scavengers who go to garbage dumps to look for abandoned property." 130 This definitional approach has been discarded in the last thirty years.

In Recognizing the Public Domain-published as early as 1981-Professor David Lange departed from the traditional line of investigation of the public domain. Lange suggested that "recognition of new intellectual property interests should be offset today by equally deliberate recognition of individual rights in the public domain." 131 Lange called for an affirmative recognition of the public domain and drafted the skeleton of a new theory for the public domain. The public domain that Lange had in mind would become a "sanctuary conferring affirmative protection against the forces of private appropriation" that threatened creative expression. ${ }^{132}$ Lange spearheaded a "conservancy model", concerned with promoting the public domain and protecting it

\footnotetext{
${ }^{125}$ Daniel Drache, Introduction: The Fundamentals of Our Time, in THE MARKET OR THE PUBLIC DOMAIN: Global GOVERNANCE AND ASYMMETRY OF POWER 1 (Daniel Drache ed., Routledge 2000).

126 See Jane C. Ginsburg, "Une Chose Publique”: The Author's Domain and the Public Domain in Early British, French and US Copyright Law, 65 CAMBRIDGE L. J. 636, 638 (2006).

${ }^{127}$ Mark Rose, Nine-Tenths of the Law: The English Copyright Debates and the Rhetoric of the Public Domain, 66 LAW \& CONTEMP. PROBS. 75, 77 (2003).

128 See Ginsburg, supra note 126, at 637.

129 William M. Krasilovsky, Observations on Public Domain, 14 Bull. Copyright SoC'Y 205 (1967).

${ }^{130}$ Pamela Samuelson, The Public Domain: Mapping the Digital Public Domain: Threats and Opportunities, 66 LAW \& CONTEMP. PROB. 147, 147 (2003).

${ }^{131}$ David Lange, Recognizing The Public Domain, 44 LAW \& ConTEMP. PROBS. 147, 147 (1981).

${ }^{132}$ Lange, supra note 25 , at 466.
} 
against any threats, that juxtaposed the traditional "cultural stewardship model" which regarded ownership as the prerequisite of productive management. ${ }^{133}$

A positive public domain propelled the "public domain project." ${ }^{134}$ For the public domain project, enclosure of the "materials that compose our cultural heritage" is a welfare loss for society. The public domain project disregards the old metaphor describing the public domain as what is "left over after intellectual property had finished satisfying its appetite" 135 and envisions copyright as "a system designed to feed the public domain providing temporary and narrowly limited rights, [. . .] all with the ultimate goal of promoting free access." ${ }^{\prime 36137}$ As Professor Lange puts it, "courts have come to see the public domain not merely as an unexplored abstraction but as a field of individual rights fully as important as any of the new property rights." 138

The legal analysis of the governance of the commons - natural resources used by many individuals in common-has inspired profoundly the modern public domain discourse. ${ }^{139}$ Environmental and intellectual property scholars started to look at knowledge as a commons - a shared resource. In 2003, the Nobel Prize Elinor Ostrom and her colleague Charlotte Hesse discussed the applicability of their ideas on the governance of common pool resources to the new realm of the intellectual public domain. ${ }^{140}$ The literature's application to governing the commons to cultural resources meant that:

\footnotetext{
133 Julie Cohen, Copyright, Commodification, and Culture: Locating the Public Domain, in THE FutURE OF THE PUBLIC DOMAIN: IDENTIFYING THE COMMONS IN INFORMATION LAW 134-135 (Lucie Guibault and P. Bernt Hugenholtz eds., Kluwer Law International 2006).

${ }^{134}$ Michael D. Birnhack, More or Better? Shaping the Public Domain, in THE FutURE OF THE PUBLIC DOMAIN, supra note 133, at 59, 60 .

${ }^{135}$ See Lange, supra note 25, at 465, n. 11 (for the "feeding" metaphor).

${ }^{136}$ James Boyle, The Second Enclosure Movement and the Construction of the Public Domain, 66 LAW \& CONTEMP. PROBS. 33, 60 (2003).

137 See RONAN DEAZLEY, RETHINKING COPYRIGHT: History, THEORY, LANGUAGE 105 (Edward Elgar Publishing 2008).

${ }^{138}$ Lange, supra note 131, at 180.

139 The main difference lies in the fact that a commons may be restrictive. The public domain is free of property rights and control. A commons, on the contrary, can be highly controlled, though the whole community has free access to the common resources. See, e.g., Wendy J. Gordon, Response, Discipline and Nourish: On Constructing Commons, 95 CORnELL L. REV. 733, 736-749 (2010).
}

${ }^{140}$ See Charlotte Hess and Elinor Ostrom, Ideas, Artifacts, and Facilities: Information as a CommonPool Resource, 66 LAW \& ConTEMP. PROBS. 111, 111 (2003); see also Michael J. Madison, Brett M. Frischmann and Katherine J. Strandburg, Constructing Commons in the Cultural Environment, 95 CoRnell L. REV. 657, 657 (2010); Elinor Ostrom and Charlotte Hess, A Framework for Analyzing the Knowledge Commons, in UNDERSTANDING KNOWLEDGE AS A COMMONS: FROM THEORY TO PRACTICE 41-81 (Charlotte Hess and Elinor Ostrom eds., MIT Press 2007). 
[t]he old dividing line in the literature on the public domain had been between the realm of property and the realm of the free. The new dividing line, drawn as a palimpsest on the old, is between the realm of individual control and the realm of distributed creation, management, and enterprise. ${ }^{141}$

The individual, legal, and market based control of the property regime is juxtaposed with the collective and informal controls of the well-run commons. ${ }^{142}$ The well-run commons can avoid the tragedy of the commons without the need of single party ownership.

The environmental metaphor has propelled what can be termed as a "cultural environmentalism," 143 which in turn inspired a new politics of intellectual property. ${ }^{144}$ The public domain is our cultural commons: it is like our air, water, and forests. As with the natural environment, the public domain-and the cultural commons that it embodies-must enjoy a "balanced and sustainable development." ${ }^{145}$ Overreaching property theory and overly protective copyright law disrupt the delicate tension between access and protection. Unsustainable cultural development, enclosure and commodification of our cultural commons will produce cultural catastrophes. As unsustainable environmental development has polluted our air, contaminated our water, mutilated our forests, and disfigured our natural landscape, unsustainable cultural development will outrage and corrupt our cultural heritage and information landscape.

Today, many academic and civic institutions have joined this movement. ${ }^{146} \mathrm{Civic}$ advocacy has also been followed by several institutional variants. Recommendation 20 of the WIPO Development Agenda endorses the goal " $[\mathrm{t}]$ o promote norm-setting activities related to IP that support a robust public domain in WIPO's Member States." ${ }^{\prime 47}$ Europe put together a diversified network of projects for the protection and promotion of the public domain, ${ }^{148}$ including COMMUNIA, the European

\footnotetext{
${ }^{141}$ Boyle, supra note 136, at 66.

${ }^{142}$ See James Boyle, Foreword: The Opposite of Property, 66 LAW \& CONTEMP. PROB. 1, 8 (2003).

${ }^{143}$ See James Boyle, Cultural Environmentalism and Beyond, 70 LAW \& CONTEMP. PROB. 5 (2007).

144 See James Boyle, A Politics of Intellectual Property: Environmentalism for the Net?, 47 DUKE L. J. 87, 110 (1997).

${ }^{145}$ See Charter of Fundamental Rights of the European Union, December 18, 2000, 2000 O.J. (C364) $1,8,37$.

146 See COMMUNIA, Survey of Existing Public Domain Competence Centers, Deliverable No. D6.01 (Draft, September 30, 2009) (on file with the author).

${ }^{147}$ See Development Agenda for WIPO, www.wipo.int/ip-development/en/agenda; see also SEVERINE Dusollier, Scoping Study On Copyright AND The Public Domain 69 (prepared for the Word Intellectual Property Organization) (April 30, 2010).

148 See Europeana: Think Culture, www.europeana.eu/portal; LAPSI: Legal Aspects of Public Sector Information, www.lapsi-project.eu; DRIVER, Digital Repository Infrastructure Vision for European
} 
Thematic Network on the Digital Public Domain. ${ }^{149}$ Cultural environmentalism's focus magnified on online commons and the Internet as the "über-commons - the grand infrastructure that has enabled an unprecedented new era of sharing and collective action." ${ }^{150}$ In the last decade, we have witnessed the emergence of a "single intellectual movement, centered on the importance of the commons to information production and creativity generally, and to the digitally networked environment in particular.",151

The modern public domain project takes over from where Kames, Jefferson, Le Chapelier, and Maculay had left it. ${ }^{152}$ Modern and earlier advocates of the public domain reject an absolutistic rhetoric of property. This rhetoric has derailed the original civic and anti-monopolistic purpose of copyright law. Public domain's enclosure runs against the historical scope of copyright. The return of the commons, in fact, has a credible source in the history of copyright law. ${ }^{153}$ Copyright law was meant to "encourage learning" and "promote progress" through the preservation of the "public sphere." The public domain is not "an unintended by product, or 'graveyard' of copyrighted works but its very goal." 154

Therefore, history would suggest a paradigmatic swift that re-defines the hierarchy of priorities. Rather than a politics of intellectual property, the policy discourse should be framed in terms of a politics of the public domain. As Francis Gurry

Research, www.driver-repository.eu; DARIAH, Digital Research Infrastructure for the Arta and the Humanities, http://www.dariah.eu.

149 See COMMUNIA, The European Thematic Network on the Digital Public Domain, http://communia-project.eu; THE PUBLIC DOMAIN MANIFESTO (2009), http://publicdomainmanifesto.org/manifesto.html; see also GIANCARLO F. Frosio, COMMUNIA FINAL REPORT ON THE DIGITAL PUBLIC DOMAIN (report prepared for the European Commission on behalf of the COMMUNIA Network and the NEXA Center) (2012), available at http://communiaproject.eu/final-report; Giancarlo F. Frosio, COMMUNIA and the European Public Domain Project: A Politics of the Public Domain, in Communia, The Digital Public Domain (Juan Carlos De Martin and Melanie Dulong de Rosnay eds., OpenBooks Publishers, 2012).

${ }^{150}$ David Bollier, The Commons as New Sector of Value Creation: It's Time to Recognize and Protect the Distinctive Wealth Generated by Online Commons, Remarks at the Economies of the Commons: Strategies for Sustainable Access and Creative Reuse of Images and Sounds Online Conference (Amsterdam, April 12, 2008), available at http://www.onthecommons.org/content.php?id=1813.

151 Yochai Benkler, The Wealth of Networks: How Social Production Transforms MARKETS AND FREEDOM 10 (Yale University Press 2007)

152 See Frosio, supra note 149, at 116-120.

${ }^{153}$ See Karl-Nikolaus Peifer, The Return of the Commons - Copyright History as a Common Source, in PRIVILEge AND Property. EsSAys ON THE History OF COPYRIGHT 348 (Ronan Deazley, Martin Kretschmer and Lionel Bently eds., Open Book Publishers 2010).

${ }^{154}$ Michael D. Birnhack, More or Better? Shaping the Public Domain, in THE FUTURE OF THE PUBLIC DOMAIN: IDENTIFYING THE COMMONS IN INFORMATION LAW 60 (Lucie Guibault and P. Bernt Hugenholtz eds., Kluwer Law International 2006). 
pointed out, focus should lie on "cultural policy," rather than intellectual property. ${ }^{155}$ Any public policy of creativity should promote the idea that "information is not only or mainly a commodity; it is also a critically important resource and input to learning, culture, competition, innovation and democratic discourse." 156 The agenda of the information society cannot be dictated by commercial interests alone. Therefore, "intellectual property must find a home in a broader-based information policy, and be a servant, not a master, of the information society." "157

As a preliminary action to turn the policy focus on the public domain and public interest, the delicate balance between private entitlements and the public domain should always be tested in advance of the enactment of any policy "by an empirical 'environmental impact statement' which details the effects of any proposal on the public domain and on public rights of access to cultural and scientific material." 158 Together with this preliminary action, before the recognition of any intellectual property interests, a politics of the public domain must set up the "deliberate recognition of individual rights in the public domain." 159 A politics of the public domain must provide positive protection of the public domain from appropriation and promotion of its reusability, access and preservation. ${ }^{160}$ Several alternative or cumulative actions may then follow to shape a new politics of the public domain. As I have argued elsewhere, together with the COMMUNIA network, ${ }^{161}$ possibly a politics of the public domain should (I) redress the many tensions with copyright protection by re-discussing term of protection, re-empowering exceptions and limitations, harmonizing relevant rules and adapting them to the technological

155 See Francis Gurry, The Future of Copyright, speech delivered at the Blue Sky Conference: Future Directions in Copyright Law, Queensland University of Technology, Brisbane, Australia (February 25, 2011).

156 Samuelson, supra note 130, at 171.

${ }^{157} I d$., at 171-172.

158 See Frosio, supra note 149, at 125-126.

${ }^{159}$ Lange, supra note 131, at 147.

${ }^{160}$ A now apparently deceased Brazilian copyright reform proposal used to be a statutory example of affirmative protection of the public domain See Lei No. 9610, de 19 de Fevereiro de 1998, Atualizada com as mudanças da Minuta de Anteprojeto de Lei que está em Consulta Pública [updated with the changes to the draft law which is under public consultation] (June 12, 2010), available at http://www.cultura.gov.br/ consultadireitoautoral/lei-961098-consolidada. The proposal endorsed the principle that anyone who obstructs the use of works fallen in the public domain is to be subject to appropriate sanctions. Id., at Art. 107, I, $\S 1$, b). The same penalties should apply to whom hinders or prevents fair or privileged uses of copyrighted works. Id., at Art. 107, I, § 1, a). In particular, the proposal aimed to assure that technological protection measures have time limited effects that will not surpass copyright expiration and do not impede privileged uses. Therefore, the bill allowed the circumvention of DRM technologies to make privileged uses or after copyright expiration. Id., at Art. 107, IV, $\S 2$ and 3.

${ }^{161}$ See Frosio, supra note 149, at 125-126. 
change; (II) positively protect the public domain against misappropriation and technological protection measures; (III) propel digitization projects and conservation of human cultural heritage by solving the orphan works problem and implementing a registry system; (IV) open access to research and public sector information; (V) promote new business models to enhance creativity including alternative remuneration systems and cultural flat rate.

As David Lange said, we all are citizens of the public domain. ${ }^{162}$ Public domain enclosure deprives citizens of their country. Policy should nourish, protect, and promote this citizenship right. Any such policy should make, for every citizen, the public domain "a place like home, where, when you go there, they have to take you in and let you dance."163

\section{REIMAGINING GATEKEEPERS}

Re-imagining copyright through the lens of a new paradigm that revives premodern into post-modern approaches to creativity does encompasses fundamentally re-imagining also the role of gatekeepers. Perhaps, here lies the true challenge where imagination must struggle the most with reality and its reactionary resistance. Mass empowerment triggers reactionary effects. Change has always unleashed a fierce resistance from the established power, both public and private. It did so with the Printing Revolution. It does now with the Internet Revolution. For public power, the emergence of limitless access, knowledge, and therefore freedom, is a destabilizing force that causes governments to face increasing accountability and therefore relinquish a share of their power. Private power sees in mass empowerment, Internet and global access to knowledge the dreadful prospective of having to switch from a top-down to a bottom-up paradigm of consumer consumption. Much to the dismay of the corporate sector, the Internet presents serious obstacles for the management of consumer behavior. As Patry noted, "copyright owners' extreme reaction to the Internet is based on the role of the Internet in breaking the vertical monopolization business model long favored by the copyright industries [ . . ] [t]he Copyright Wars are an effort to accomplish the impossible, to change the Internet into a vehicle for the greatest form of vertical monopolization ever seen . . .."164 In particular, the steady enlargement of copyright becomes a tool used by reactionary forces willing to counter the Digital Revolution. From a market standpoint, stronger rights allow the private sector to enforce a top-down consumer system. The emphasis of copyright protection on a permission culture favours a unidirectional market, where the public is only a consumer, passively engaged to pay-per use or stop using copyrighted

\footnotetext{
162 Lange, supra note 25 , at 475.

${ }^{163} I d$., at 470 .

${ }^{164}$ See William Patry, Moral Panics AND the Copyright Wars 31-34 (Oxford U. Press 2009) (eBook Adobe Digital Editions).
} 
works. ${ }^{165}$ From a political standpoint, a tight control on reuse of information will prevent mainstream culture to be challenged by alternative culture. Copyright law would serve to empower mainstream culture and marginalize minority alternative counter-culture, therefore relenting any process leading to a paradigm shift. ${ }^{166}$

From a broader socio-economic perspective, there is also a more systemic explanation to the reaction facing the emergence of the networked information society. Baudrillard's arguments might be useful to explain the reaction to the Digital Revolution driving cultural goods' marginal cost of distribution and reproduction close to zero. ${ }^{167}$ Copyright law might become an instrument to protect the capitalistic notion of consumption and perpetuate a system of artificial scarcity. Insomuch the Digital Revolution turns consumers into users and then creators, it defies the very notion of consumer society. It turns the capitalistic consumer economy into a networked information economy, which is characterized by sharing and gift economy. So, for the socio-economic consumerist paradigm not to succumb, the limitless power of peer and mass collaboration must be tamed by the artificial scarcity created by copyright law. Ultimately, resistance to the Digital Revolution can be seen as a response to Baudrillard's call to a return to prodigality beyond the structural scarcity of the capitalistic market economy. ${ }^{168}$ The Internet and networked peer collaboration may represent a return to "collective improvidence or prodigality" and its related "real affluence." ${ }^{169}$ New Internet dynamics of exchange and creativity might answer in the positive Baudrillard's question whether we will "return, one day, beyond the market economy, to prodigality." 170 In Baudrillard's terms, by increasingly commodifying knowledge and expanding copyright protection, we are taming limitless power with artificial scarcity to keep in place a "dialectic of penury" and unlimited need. ${ }^{171}$ Therefore, the reaction to the Internet revolution may be construed as a gatekeepers' attempt to keep in place their privileges as they thrive within a paradigm that builds the need of production - and overproduction-over an obsession with scarcity through the creation of artificial scarcity.

${ }^{165} C f$. id, at 35 .

${ }^{166}$ I have discussed the effects of copyright expansion on semiotic democracy - with a comprehensive review of literature on point - in a previous piece of mine to which I remand. See Frosio, supra note 11 , at 376-390.

${ }^{167}$ For a more detailed discussion of Baudrillard's categories as applied to cyberspace and the Digital Revolution, see Giancarlo Frosio, User Patronage: the Return of the Gift in the "Crowd Society", 2015(5) Mich. ST. L. REV. 1983-2046 (2015).

168 See JeAn Baudrillard, The CONSUMER Society: Myths AND STRUCTURes 66-68 (SAGE Publ. 2007) (1970)

${ }^{169} I d$., at 67.

${ }^{170} I d$., at 68 .

${ }^{171}$ Id., at 67. 
In the dedication to the Expositiones in Summulas Petri Hispani-printed around 1490 in Lyons - the editor, Johann Trechsel, announced: "[i]n contrast to xylography, the new art of impression I am practicing ends the career of all the scribes. They have to do the binding of the books now." ${ }^{172}$ Similarly, in the digital era, the role of distributors might change and they might be forced to redefine their function. One of the key lessons in the gradual shift in market power in the entertainment industry these days is that the power of the old gatekeepers is declining, even as the overall industry grows. The power, instead, has definitely moved directly to the content creators themselves. Creators no longer need to go through a very limited number of gatekeepers, who often provide deal terms that significantly limit the creator's ability to make a living. Instead, a major new opportunity has opened up, not for gatekeepers, but for organizations that enable artists to do the different things that the former gatekeeper used to do-but while retaining much more control, as well as a more direct connection with fans. As discuss at length in another piece of mine, ${ }^{173}$ there have been emerging multiple organizations enabling a direct discourse between artists and users, such as Kickstarter, TopSpin or Bandcamp. ${ }^{174}$ As a consequence, traditional cultural intermediaries might be forced to give up their Ancien Régime's privileges, thus causing further resistance to change. In the words of Nellie Kroes, European Commission Vice-President for the Digital Agenda,

[a]ll revolutions reveal, in a new and less favourable light, the privileges of the gatekeepers of the "Ancien Régime". It is no different in the case of the internet revolution, which is unveiling the unsustainable position of certain content gatekeepers and intermediaries. No historically entrenched position guarantees the survival of any cultural intermediary. Like it or not, content gatekeepers risk being sidelined if they do not adapt to the needs of both creators and consumers of cultural goods. [...] Today our fragmented copyright system is ill-adapted to the real essence

\footnotetext{
${ }^{172}$ Uwe Neddermeyer, Why Were There No Riots of the Scribes? First Result of a Quantitative Analysis of the Book-production in the Century of Gutenberg, 31 GAZETTE DU LIVRE MÉDIÉVAL 1, 7 (1997). Surprisingly, at the time of the printing revolution, the resistance to the new technology was little. Only few protests from scribes were recorded throughout Europe. See id., at 4-5 (reporting protests in Genoa in 1472, in Augsburg in 1473, and in Lyon in 1477); see also PETER BURKE, THE ItAlian RenAissance: Culture AND SOCIETY IN ITAly 71 (Princeton U. Press 1999) (noting the adaptability of several scribes, who became printers themselves). Reconversion from old to new jobs was smooth. A variety of new jobs was created and there are no indications of unemployment or poverty suffered by any part of society due to the introduction of the new technology. See Neddermeyer, supra, at 5-7; CYPRIAN Blagden, THE STATIONERS' COMPANY: A HistORY, 1403-1959 23 (Stanford U. Press 1977) (reporting that "there is no evidence of unemployment or organized opposition to the new machines" in England). Quite the contrary, in the last quarter of the fifteenth century more money was spent on books that any time before. Id.

${ }^{173}$ See Frosio, supra note 167, at 2039-2046.

${ }^{174}$ See Michael Masnick and Michael Ho, The SKy is Rising: A Detailed Look at the State OF THE ENTERTAINMENT INDUSTRY 5-6 (Floor 64, January 2012), available at http://www.techdirt.com/skyisrising.
} 
of art, which has no frontiers. Instead, that system has ended up giving a more prominent role to intermediaries than to artists. It irritates the public who often cannot access what artists want to offer and leaves a vacuum which is served by illegal content, depriving the artists of their well-deserved remuneration. And copyright enforcement is often entangled in sensitive questions about privacy, data protection or even net neutrality. [...] It may suit some vested interests to avoid a debate, or to frame the debate on copyright in moralistic terms that merely demonise millions of citizens. But that is not a sustainable approach. [...] My position is that we must look beyond national and corporatist self-interest to establish a new approach to copyright. ${ }^{175}$

\section{Reimagining Copyright Alternative BuSiness ModelS}

Neelie Kroes stressed that copyright fundamentalism has prejudiced our capacity to explore new models in the digital age:

So new ideas which could benefit artists are killed before they can show their merit, dead on arrival. This needs to change. [ . . ]. So that's my answer: it's not all about copyright. It is certainly important, but we need to stop obsessing about that. The life of an artist is tough: the crisis has made it tougher. Let's get back to basics, and deliver a system of recognition and reward that puts artists and creators at its heart. ${ }^{176}$

This crisis of the notion of copyright propelled proposals for reform tackled the uneasy coexistence between copyright, digitization and the networked information economy. They attempt to fix copyright to promote creativity within the emerging cumulative, collaborative and open access norms of the information society.

In search of alternative remuneration systems, researchers, activists, consumer organizations, artist groups, and policy makers have proposed to finance creativity on a flat-rate base. ${ }^{177}$ In the past, levies on recording devices and media have been set up upon the acknowledgment that private copying cannot be prevented. ${ }^{178}$ The

\footnotetext{
${ }^{175}$ Neelie Kroes, European Commission Vice-President for the Digital Agenda, A Digital World of Opportunities, speech delivered at the Forum d'Avignon - Les Rencontres Internationales de la Culture, de l'Économie et des Medias, Avignon, France, SPEECH/10/619 (November 5, 2010).

${ }^{176}$ Neelie Kroes, Who feeds the artist?, speech delivered at the Forum d'Avignon - Les Rencontres Internationales de la Culture, de l'Économie et des Medias, Avignon, France, SPEECH/11/777 (November 19, 2011), available at http://europa.eu/rapid/pressReleasesAction.do?reference=SPEECH\%2F11\%2F777.

177 Volker Grassmuck, The World is Going Flat(-Rate): A Study Showing Copyright Exception for Legalizing File-Shearing Feasible as a Cease-Fire in the "War on Copyright" Emerges, INTELLECTUAL PROPERTY WATCH, May 11, 2009, http://www.ip -watch.org/weblog/2009/05/11/theworld-is-going-flat-rate.

${ }^{178}$ In the analog environment, many national legislations implemented quasi flat rate models and different arrangements of private copying levies that may be envisioned as a form of cultural tax. Private copying levies are special taxes, which are charged on purchases of recordable media and copying devices and then redistributed to the right holders by means of collecting societies. See, e.g., MARTIN KRETSChMER, PRIVATE COPYING AND FAIR COMPENSATION: AN EMPIRICAL STUDY OF
} 
same reasoning would apply to the introduction of a legal permission to copy and make available copyrighted works by individuals for non-commercial purposes in the Internet. ${ }^{179}$ Flat rate proposals would favour a sharing ecology that is best suited to the networked information economy.

A study of the Institute of European Media Law (EML) has argued that this may be "nothing less than the logical consequence of the technical revolution introduced by the internet." 180 This study also described the minimum requirements for a cultural flat-rate as follows: (i) a legal licence permitting private individuals to exchange copyright works for non-commercial purposes; (ii) a levy, possibly collected by the ISPs, flat, possibly differentiated by access speed; and (iii) a collective management, i.e. a mechanism for collecting the money and distributing it fairly. ${ }^{181}$ On the basis of the EML study, the German and European Green Parties included in their policy agenda the promotion of a cultural flat rate to decriminalise P2P users, remunerate creativity and relieve the judicial system and the ISPs from mass-scale prosecution. The EML study found that a levy on Internet usage legalising non-commercial online exchanges of creative works conforms with German and European copyright law, even though it requires changes in both. ${ }^{182}$

Several other flat-rate models have been proposed. ${ }^{183}$ A non-commercial use levy permitting non-commercial file sharing of any digitised work was firstly proposed by Professor Neil Netanel. ${ }^{184}$ Such levy would be imposed on the sale of any consumer electronic devices used to copy, store, send or perform shared and downloaded files but also on the sale of internet access and p2p software and services. An ad hoc body would be in charge of determining the amount of the levy. The proceeds would be distributed to copyright holders by taking into consideration the popularity of the works to be measured by tracking and monitoring technologies. Users could freely copy, circulate and make non-commercial use of any works that the right holder has

COPYRIGHT LEVIES IN EUROPE (October 2011) (report prepared for the UK Intellectual Property Office).

${ }^{179}$ See Hugenholtz, Bernt, Lucie Guibault And Sjoerd VAn GefFen, The Future Of LeVIes In A DigitAL ENVIRONMENT (Institute for Information Law 2003).

${ }^{180}$ INSTITUT FÜR EUROPÄISCHES MEDIENRECHT [INSTITUTE OF EUROPEAN MEDIA LAW] (EML), DIE ZULÄSSIGKEIT EINER KULTURFLATRATE NACH NATIONALEM UND EUROPÄISCHEM RECHT [THE Admissibility of a Cultural Flat Rate under National and European LaW] 63 (March 13, 2009) (study prepared for the German and European Green Party).

${ }^{181} \mathrm{Id}$.

${ }^{182} \mathrm{Id}$.

183 See Alain Modot, Héloïse Fontanel, Nic Garnett, Erik lambert, André Chaubeau,

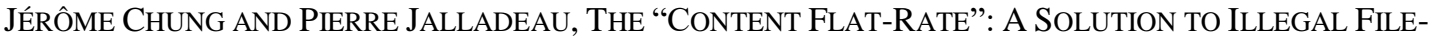
SHARING? STUDY (study prepared for the European Parliament) (July 2011).

${ }^{184}$ Netanel Neil W., Impose A Noncommercial Use Levy To Allow Free Peer-To-Peer File Sharing, 17 HARV. J. L. \& TECH. 1 (2003). 
made available on the Internet. William Fisher followed up on Netanel with a more refined and comprehensive proposal. ${ }^{185}$ Creators' remuneration would still be collected through levies on media devices and Internet connection. In Fisher's system, however, a governmentally administered registrar for digital content, or alternatively a private organization, would be in charge of the management of creative works in the digital environment. Digitised works would be registered with the Registrar and embedded with digital watermarks. Tracking technologies would measure the popularity of the works circulating online. The Registrar would then redistribute the proceedings to the registered right holders according to popularity of the works.

Again, Philippe Aigrain proposed a "creative contribution" encompassing a global licence to share published digital works in the form of extended collective licensing, or, absent an agreement, of legal licensing. ${ }^{186}$ Remuneration would be provided by a flat-rate contribution that will be paid by all Internet subscribers. Half of the money collected would be used for the remuneration of works that have been shared over the Internet according to their popularity. Measurement of popularity would be based on a large panel of voluntary Internet users transmitting anonymous data on their usage to collective management societies. The other half of the money collected would be devoted to funding the production of new works and the promotion of added-value intermediaries in the creative environment.

Proposals to apply ECL to legitimize file-sharing have been also advanced. Collective management bodies would negotiate the license with users' associations or internet service providers. In exchange for the right of reproducing and making available content online, rights holders will be remunerated by the proceedings collected through the extended collective license. A related proposal would place the right to make available to the public under mandatory collective management. ${ }^{187}$ According to this proposal, to enjoy the economic rights attached to the right of

185 See William W. Fisher, Promises To Keep: Technology, LaW and the Future of ENTERTAINMENT (Stanford Law and Politics 2004).

186 See Philippe Aigrain (With CONTRibution of SuZAnne Aigrain), Sharing: Culture AND the ECONOMY IN THE INTERNET AGE 59-137 (Amsterdam University Press 2012).

187 See SiLKE VON LEWINSKI, MANDATORY COLLECTIVE ADMINISTRATION OF EXCLUSIVE RIGHTS - A CASE STUdy On ITS COMPATIBILITY WITH INTERNATIONAL AND EC COPYRIGHT LAW (UNESCO eCopyright Bulletin, January - March 2004), available at http://portal.unesco.org/culture/en/files/19552/11515904771 $\quad$ svl_e.pdf/svl_e.pdf (discussing a proposed amendment in the Hungarian Copyright Act). See CARINE BERNAULT AND AUdREY LEBOIS UNDER THE SUPERVISION OF PROFESSOR ANDRÉ LUCAS, PEER-TO-PEER ET PROPRIÉTÉ LITTÉRAIRE ET ARTISTIQUE ETUDE DE FAISABILITÉ SUR UN SYSTÈME DE COMPENSATION POUR L'ÉCHANGE DES EEURES SUR INTERNET [PEER-TO-PEER FILE SHARING AND LITERARY AND ARTISTIC PROPERTY. A FEASIBILITY STUDY REGARDING A SYSTEM OF COMPENSATION FOR THE EXCHANGE OF WORKS VIA THE INTERNET] (June 2005) (study prepared for ADAMI and SPEDIDAM) (with the same proposal endorsed by the French Alliance Public-Artistes, campaigning for the implementation of a Licence Globale). 
making available to the public, rights holders would be obligated to use collective management. As a consequence, the ISPs would pay a lump-sum fee or levy to the collective societies in exchange for the authorization to download and make the collective society's entire repertoire available to users. The money collected would be then redistributed to the right holders.

More radically, future support for creativity may increasingly derive directly from the public. Crowd-funding and the ubiquity of digital networks may facilitate the emergence of a patronage model for creativity, in which the public might provide unfiltered and direct economic support to creativity. ${ }^{188}$ Experiments with pay-as-youwish pricing in the music industry reveal that fans will voluntarily pay far more for their favorite music than economic models would ever predict. ${ }^{189}$ For example, Bandcamp - a platform that lets musicians set up simple content stores for their works and allows for streams, pay-what-you-want, free or conditional downloadshelped artists to make over one million dollars a month. Bandcamp states that when given the option of paying-what-you-want for albums with a suggested price, fans pay an average of fifty percent more than the minimum price. ${ }^{190}$ The data suggest that artists have increasingly valuable opportunities to go directly to fans, rather than surrendering revenue streams to gatekeepers. Consumers are often willing to spend more if they feel that they are really getting something of value and there is a direct connection to the artist. In this sense, TopSpin Media- a company providing tools to content creators to allow them to promote a direct-to-fan marketing and retail-is another interesting example. According to TopSpin Media, the average transaction price increased from $\$ 22$ to $\$ 26$ over a year, with a pick of $\$ 88$ for offers including a ticket for a live event. ${ }^{191}$

The ubiquitous power of Internet networks has made possible a direct connection between artists and the public to support the creative process in innovative ways. ${ }^{192}$ In particular, digital crowd-funding is an increasingly popular tool to raise money

\footnotetext{
${ }^{188}$ For a full discussion of the idea of user patronage - and a review of the economics of creativity form a historical perspective_-see Frosio, supra note 167.

189 See Yochai Benkler, The PEnguin And the LeViathan: How COOPERATION TRIUMPHS OVER SELF-INTEREST 147-149 (Crown Business 2011); see also CHRIS ANDERSON, Free: The Future of a Radical Price (Hyperion Books 2009); Chris Anderson, THE LONG TAIL: Why THE Future OF BUSINESS IS SELLING LESS FOR MORE (Hyperion Books 2006).

${ }^{190}$ See Bandcamp, www.bandcamp.com.

${ }^{191}$ See TopSpin Media, http://www.topspinmedia.com; see also MASNICK AND Ho, supra note 174, at 5 .

192 See Michael Carrier, No, RIAA, It's Not the End of the World for Musicians, 83(2) UMKC L. Rev 287, 287-302 (2014) (showing how technology has made it easier for musicians to participate in every step of the process: creation (GarageBand), distribution (Twitter, YouTube), marketing (Topspin, Bandcamp), royalty collection (CD Baby Pro, TuneCore), crowdfunding (Kickstarter, Indiegogo), and touring (Songkick, Bandsintown); this in turn has made easier for musicians to forge stronger connections with fans).
} 
online. ${ }^{193}$ On Kickstarter and similar platforms, people can pledge for an economic goal, which is set up in advance by the project developer. Kickstarter works by giving artists a way to let fans crowdfund the creation of new works. It lets artists offer different tiers, through which fans can help fund a project, in the hope of reaching a funding threshold. Only after the threshold is met does the money change hands. As of September 2015, almost two billion dollars have been pledged to artists through Kickstarter. ${ }^{194}$ There are 253,937 launched projects with a success rate of 37.05 percent. Kickstarter's stats also report that 91,931 projects were successfully funded and approximately 1.66 billion dollars made to successful projects. Kickstarter's successful stories have become countless. Kickstarter funds all sorts of creative works, and so far, almost $\$ 400$ million was pledged to games, almost $\$ 300$ million was pledged to film and video, over $\$ 154$ million pledged to music, and nearly $\$ 80$ million pledged to publishing.

Of course, Kickstarter is just one of a number of similar platforms, such as ArtistShare, SellaBand, IndieGoGo, PledgeMusic, AfricaUnsigned, MyMajorCompany, Mobcaster, TubeStart, Pozible, Wishberry, CentUp, Crowdfunder, or Ulule. ${ }^{195}$ These services may apply an "all or nothing" or a "keep it all" model. In the latter case, the funds collected are handed over to the campaigner, regardless of whether the project goal is met or not. Other crowdfunding platforms, such as Bountysource, Patreon, or Sprked, allow for a continuous funding model, rather than one-time donation, for those creators making content on a regular basis. ${ }^{196}$ There are also services allowing users to award creators after the works have been published. Flattr, for example, is a microdonation application that displays this information alongside the content. ${ }^{197}$ An internet user would give between 2 and

${ }^{193}$ For a general overview of crowdfunding and literature review, see Moritz, Alexandra and Jorn H. Block, Crowdfunding: A Literature Review and Research Directions, in CROWDFUNDING IN EUROPE: STATE Of THE ART IN THEORY AND PRACTICE 25-53 (Dennis Brüntje and Oliver Gajda eds., Springer 2015).

${ }^{194}$ See Kickstarter, Stats, https://www.kickstarter.com/help/stats.

195 See ArtistShare, www.artistshare.com (music); SellaBand, www.sellaband.com (music); IndieGoGo, www.indiegogo.com (miscellaneous); PledgeMusic, www.pledgemusic.com (music); AfricaUnsigned, www.africaunsigned.com (music); MyMajorCompany, www.mymajorcompany.com (film \& video); Mobcaster, http://mobcaster.com (TV shows); TubeStart, www.tubestart.com (YouTube video Creator); Pozible, www.pozible.com (creative projects); Wishberry, www.wishberry.in (creative projects); CentUp, www.centup.org (blogger, podcasters, web-based publishers); Crowdfunder, www.crowdfunder.co.uk (miscellaneous); Ulule, www.ulule.com (miscellaneous).

196 See Bountysource, www.bountysource.com (open-source software); Patreon, www.patreon.com (music, podcasts, vloggers, YouTube videos, webcomics); Sprked, https://sprked.com (gaming content).

197 See Flattr, https://flattr.com. 
100 euros per month and could then nominate works that they wish to reward or "flattr," a play on the words "flatter" and "flat-rate". ${ }^{198}$

\section{CONCLUSIONS: RE-IMAgINING CREATIVITY FROM COMMON ROOTS}

The notion of creativity in the East and West - as well as Global North and Global South-shares common roots. For millennia, it was based on openness, participation and inclusiveness, rather than exclusive rights. From Confucius to Plato-and the tradition they shaped for very long time-originality, imitation, and borrowing coexisted as part of a collective, cumulative and collaborative creative model. Creative paradigms departed at about the time of the Enlightenment when the Western perception of creativity took a more markedly individualistic direction. This has led to over-propertization of intellectual entitlements. In time, this Western model - especially after TRIPs - has been exported internationally. At least, this has been the plan on the agenda for quite some time now. In truth, he assimilation into the Western creative model runs counter to the desire of the Global South to reclaim cultural identity from imperial power. Rather than concluding that "resistance is futile," the non-Western world should be guided by the idea that "[a]assimilation in an unworthy society is an unworthy goal." 199 Johanna Gibson talks about a grand plan of intellectual property and interpretation of knowledge in modern Western societies and contrasts it with other social arrangements. Gibson noted:

The self-esteem and social worth derived from propertied success in the western world, is incompatible with the principles of individual subjectivity premised upon community in traditional and Indigenous communal philosophies, where "the individual feels socially worthy and important because his or her role and activity in the community are appreciated. The system affords the individual the opportunity to make a meaningful life through his or her contribution to general welfare."200

A global movement has emerged challenging the Western intellectual property model, its over-expansive propertarian emphasis, its apparent inconsistencies with technological innovation and the transformation in the creative economics it has brought about. Building upon it vision-I'd like to sketch out a roadmap for reform that reconnects Eastern and Western creative experience in light of a common past, looking for a shared future. This roadmap would like to reshape the interplay

\footnotetext{
${ }^{198} I d$.

199 MARILYN FRENCH, BEYOND POWER 474 (1985).

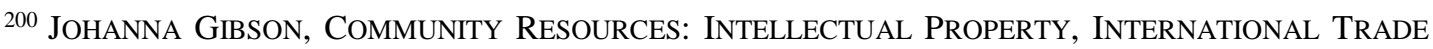
And Protection of Traditional KnOWledge 73 (Ashgate 2005) citing KwAME GyeKye, AN Essay on African Philosophical Thought: The AKan ConcePtual Scheme (Temple U. Press 1995).
} 
between community, law, and market to envision a system that may fully exploit the digital opportunity by looking at history of creativity as a guidance. ${ }^{201}$

The roadmap for reform I envision would emphasize the role of the users, the necessity to rethink users' rights, and users' involvement in the legislative process. So far, users have had very limited access to the bargaining table when copyright policies had to be enacted. This is due to the dominant mechanics of lobbying that largely excluded users from any policy decisions. This led to the implementation of a copyright system that is strongly protectionist and pro-distributors. Further, in the networked, peer and mass productive environment, creativity seeks a politics of inclusive rights, rather than exclusive. This is a paradigmatic swift that would redefine the hierarchy of priorities by thinking in terms of "cultural policy" and developing a politics of access and politics of the public domain, rather than a politics of intellectual property. Before the recognition of any intellectual property interests, a politics of the public domain must set up the "deliberate recognition of individual rights in the public domain" and positively protect it from appropriation. ${ }^{202}$ Again, a politics of inclusive rights, access, and the public domain seek the demise of copyright exclusivity to reconnect the creative process with its traditional cumulative and collaborative nature. ${ }^{203}$ In turn, additional mechanisms should provide economic incentive to creation, such as a liability rule integrated into the system or an apportionment of profits. A politics of inclusivity would de-construe the post-romantic paradigm over-emphasizing creative individualism and absolute originality and adapt to networked and user-generated creativity. Finally, alternative compensation systems will gradually substitute traditional copyright business models. Perhaps, in the future, the transition to a consumer gift system or user patronage, through digital crowd-funding, would make support for creativity increasingly derive from a direct and unfiltered discourse between authors and the public.

Reimagining copyright to make it fit to the digital environment does entail reimagining users' rights, policy approaches, copyright exclusivity and copyright

\footnotetext{
${ }^{201}$ Individual components of this roadmap for reform have been described in previous works of mine - to which I refer in this article. A more detailed review of this roadmap for reform-with each component of the proposal acting as a pillar for a metaphorical temple dedicated to the enhancement of creativity - will be the subject of Chapter 10, The Temple of Digital Enlightenment, of my forthcoming book RECONCILING COPYRIGHT WITH CUMULATIVE CREATIVITY: THE THIRD PARADIGM (Edward Elgar 2018).

${ }^{202}$ See, for further discussion of a politics of the public domain, Frosio, supra note 149; Frosio, supra note 149 .

${ }^{203}$ This proposal — and the historical interdisciplinary research that serves as a background — has been discussed at length in previous works of mine to which I refer. See Frosio, supra note 11; Giancarlo F. Frosio, A History of Aesthetics from Homer to Digital Mash-ups: Cumulative Creativity and the Demise of Copyright Exclusivity, 9(2) LAW AND HuMANITIES 262-296 (2015), available at http://www.tandfonline. com/doi/full/10.1080/17521483.2015.1093300
} 
business models. Given emerging new economics and social perception of creativity online, modern copyright policies should be reimagined through lens magnifying on access and a positive notion of the public domain. Copyright exclusivity should be also reimagined by crafting within the system a new incentive formula, communitarian rather than individualistic, inclusive rather than exclusive, which might propel creativity though the power of imitation. Inclusivity might help reimagining gatekeepers and business models for creativity to be newly designed around gift economy approaches, crowdfunding and user-author interactions. The power of imitation reaches far from the Confucian-Platonic tradition into modern digital creative practices based on remix and communitarian reactions. It should be given again a leading role in modern policies for creativity, reconciling pre-modern, modern and post-modern approaches to creativity, copyright and cumulative creativity, and Western and Eastern visions. 